\title{
Lacustrine couplet-lamination: evidence for Late Pennsylvanian seasonality in central equatorial Pangaea (Stephanian B, Mšec Member, Central and Western Bohemian basins)
}

\author{
RICHARD LOJKA, IVANA SÝKOROVÁ, JIŘí LAURIN, PETRA MATYSOVÁ \& TOMÁŠ MATYS GRYGAR
}

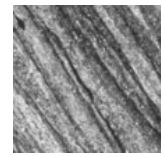

\begin{abstract}
A large freshwater lake formed (lake area $\left.>5000 \mathrm{~km}^{2}\right)$ during the Stephanian B $(\sim 304 \mathrm{My})$ period of the Late Pennsylvanian in the central-east equatorial Pangaea and covered a substantial part of the continental Late Palaeozoic basins in the central Bohemian Massif (the Czech Republic). Lacustrine mudstones of the Mšec Member were acquired from two shallow boreholes $80 \mathrm{~km}$ apart and were analysed for lamination structure and periodicity, mineral composition and dispersed organic matter, in order to obtain more detailed information on the palaeoenvironmental change with a near annual resolution. Two hydrological states of the lake were identified, including high lake-level periods with dysoxic conditions on the lake floor, under a permanently thermally stratified hypolimnion favouring organic matter production and storage during periods of condensed sedimentation producing an irregular lamination pattern. A series of continuous regular couplet lamination reflect conditions of partially, possibly seasonally stratified hypolimnion with advanced lake-water mixing and organic matter oxidation. The couplet lamination results from an alternation of organic-clay laminae, consisting of variable proportions of autochthonous algal and microbial organic remnants, with detrital silt laminae accompanied by authigenic siderite and humified or burnt terrestrial plant debris. Similarly as in some modern tropical lakes, such regular high-frequency variations in sediment supply suggest seasonal changes in rainfall to be responsible for couplet formation. Couplet thickness distribution shows statistically significant periodicities, resembling multiannual to multidecadal scales observed in recent sediment archives, and so indirectly supports seasonality in precipitation in Pangaean low-latitudes, at least during part of the Stephanian B. • Key words: lamination, cyclicity, freshwater lake, dispersed organic matter, siderite, palaeoclimate.
\end{abstract}

LOJKA, R., SÝKOROVÁ, I., LAURIN, J., MATYSOVÁ, P. \& MATYS GRYGAR, T. 2010. Lacustrine couplet-lamination: evidence for Late Pennsylvanian seasonality in central equatorial Pangaea (Stephanian B, Mšec Member, Central and Western Bohemian basins). Bulletin of Geosciences 85(4), 709-734 (15 figures, 1 table, 3 appendices). Czech Geological Survey, Prague. ISSN 1214-1119. Manuscript received September 1, 2010; accepted in revised form December 6, 2010; published online December 20, 2010; issued December 20, 2010.

Richard Lojka, Czech Geological Survey, Klárov 3/131, 11821 Praha 1, Czech Republic \& Institute of Inorganic Chemistry of the ASCR, v.v.i., $25068 \check{R} e z ̌$, Czech Republic; richard.lojka@geology.cz•Ivana Sýkorová \& Petra Matysová, Institute of Rock Structure and Mechanics of the ASCR, v.v.i., V Holešovičkách 41, 18209 Praha 8, Czech Republic •Jiři Laurin, Institute of Geophysics of the ASCR, v.v.i., Boční II/1401, 14131 Praha 4, Czech Republic • Tomáš Matys

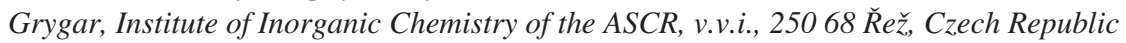

Global Pennsylvanian-Permian climate developed cyclically within several time scales. Between the Viséan and early Sakmarian, polar ice sheets were formed (Veevers \& Powell 1987, Roscher \& Schneider 2006) to an extent comparable to that in the Pleistocene (Frakes \& Francis 1988; Crowley \& Baum 1991, 1992; Crowell 1999). The equatorial Pangaea underwent long-term drying accompained by increasing seasonal contrasts during the Late Pennsylvanian, low-latitude aridisation and further harshening of seasonal contrasts during the Permian (Tabor \& Poulsen 2008). The southern Gondwanan ice sheet was unstable with several My episodes of quasi-periodicity, several "deglaciation" cycles were revealed by environmental changes in the high southern latitudes (Visser 1997, Scheffler et al. 2003, Fielding et al. 2008), although their exact number and timing has not been established yet, neither their correlation with climate changes in Pangaean low latitudes. Similarly, the driving force for this periodicity remains unknown (Roscher \& Schneider 2006).

Recent more detailed examination of sediments accumulated in equatorial Pangaean basins during the Late Pennsylvanian and Early Permian has shown several periods of 
more humid climate (Opluštil \& Cleal 2007, Schneider et al. 2006, Tabor \& Poulsen 2008), which were correlated to these southern Gondwanan "deglaciations" by some authors (Roscher \& Schneider 2006). The Barruelian (Roscher \& Schneider 2006), also called Stephanian B (Opluštil \& Cleal 2007) humid phase is recorded in the Central and Western Bohemian basins (Fig. 1) by the coal-bearing Slaný Formation that includes a widespread lacustrine-deltaic unit within the Malesice Member, embedded between the two main coal-bearing units of the Mělník and Kounov group of seams. Lacustrine fine siliciclastics represent the most reliable continental archives if the lakes were perennial and sufficiently large to be capable of recording at least regional conditions (Parrish 1998, Cohen 2003).

One such extended and deep freshwater lake formed in the Stephanian B, Late Pennsylvanian, in the north-eastern part of the Bohemian Massif producing a $\sim 20$ m thick unit of more or less laminated organic-rich fine siliciclastics. Its stratigraphic position and continuous record provides a unique opportunity for detailed analysis of climate variability during a rather short humid episode during a long-term drying trend in equatorial Pangaea. The Mšec Member serves as a stratigraphic correlation for practically all Western and Central Bohemian and Lausatian basins in the Czech Republic (Pešek 1994, Pešek et al. 2001), hence it has been studied for several decades (Obrhel 1958; Skoček 1968, 1990; Holub et al. 1975; Lojka et al. 2009) and represents one of the largest and best documented lakes of that period and latitude $\left(0-5{ }^{\circ} \mathrm{N}\right)$. Climate modelling (Roscher et al. 2008) suggested that since the Late Pennsylvanian to Early Permian the marginal belt of eastern equatorial Pangaea, including the Bohemian Massif, was a seasonally humid tropical region with substantial oceanic character although the westward European basins were exposed to a drier climate. Strengthening and weakening of seasonal forces accompanied by variation in the total annual precipitation would most likely be a major control on the environmental development of Pangaean continental tropics of that period.

The aim of this report is to provide a detailed description of the recorded lamination, particularly its structural and compositional variations and cyclicity, as this provides direct evidence of seasonal variation in precipitation possibly related to the monsoonal circulation, which is considered one of the causes of seasonal distribution of humidity during the Pennsylvanian (Soreghan \& Soreghan 2007).

\section{Geological setting}

The Late Palaeozoic Central and Western Bohemian basins originated in the middle Pennsylvanian during early post-orogenic extension in the NW part of the Bohemian
Massif. Their structural position within the Variscan fold belt predestined purely continental sedimentation accompanied by volcanic and tectonic activity. Synsedimentary tectonics was responsible for the gradual expansion of the depositional area, for two regional disconformities (Pešek et al. 2001) and probably also for the prominent change in the depositional environment expressed by the expansion of the studied lacustrine unit. The $>1400 \mathrm{~m}$ thick basin-fill, spanning the Moscovian to the Gzhelian, records a time frame of about $13 \mathrm{My}$, during which time the Bohemian basins were located in central-east equatorial Pangaea at $0-5{ }^{\circ} \mathrm{N}$ (Krs \& Pruner 1995). The basin-fill can be divided into four main formations based on palaeofloral assemblages and prevailing lithology and sediment colour (e.g. Havlena \& Pešek 1980). The two lower formations are dominated by coarse-grained fluvial deposits arranged into fining upwards successions of several different scales which are accompanied by coal seams (Kladno Formation) or well-drained calcic paleosols (Týnec Formation). The two upper formations consist mainly of lacustrine deposits accompanied by coal seams (Slaný Formation) or floodplain red beds (Líně Formation) consisting of well-drained calcic paleosols and in-situ or fluvially reworked loessite (Tásler \& Skoček 1964).

The Slaný Formation consists of several members representing different lithofacies of dominantly lacustrine and associated environments (Fig. 1). From macrofloral evidence from the Mělník and Kounov group of seams (Havlena 1961) encompassing the most characteristic part of the Slaný Formation - the Malesice Member lacustrine unit, the Slaný Formation has been established as being of Stephanian B age. Macrofloral evidence corresponds well with the quite rich freshwater faunal assemblage indicating a local Elonichthys bio/eco subzone of the Stephanian B (Zajíc 2000, 2004, 2006). While the base of the formation is transitional, its top is weathered and discordantly cut by alluvial-lacustrine red beds of Stephanian C age (Pešek 1994). The Stephanian B represents a rather narrow time interval lasting probably no longer than $1 \mathrm{My}$ (Gradstein $e t$ $a l$. 2004), during which the $<220 \mathrm{~m}$ thick Slaný Formation was deposited. The thickness of the Malesice Member lacustrine unit is roughly half that of the entire formation.

\section{Depositional setting of the Malesice Member}

The lacustrine-deltaic series of the Malesice Member are $<120 \mathrm{~m}$ thick, and form a coarsening upward unit preserved in the major part $\left(>3500 \mathrm{~km}^{2}\right)$ of the Late Palaeozoic Central and Western Bohemian basins (Skoček 1968, 1990). According to prevailing lithology, it is usually divided into the Mšec Member in the lower part, dominated by black mudstones and the overlying Hrredle Member consisting of variable sandy-silty facies (Obrhel 1958). These two 


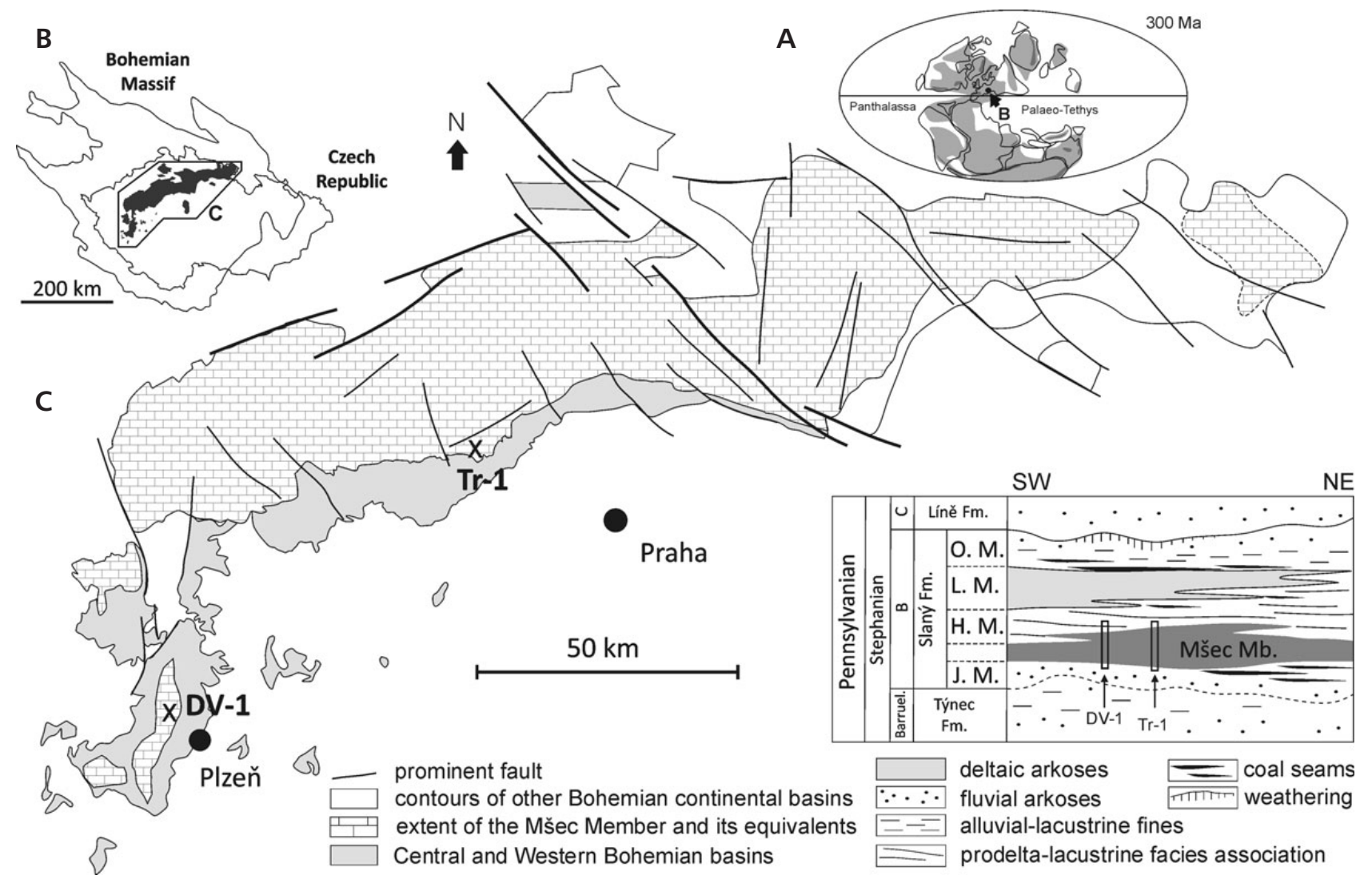

Figure 1. A - Late Pennsylvanian palaeogeographic position of the Bohemian Massif at low-latitudes. $\bullet$ B - size and position of Bohemian Late Palaeozoic continental basins in the Bohemian Massif. $\bullet$ C - geological sketch map of Bohemian Late Palaeozoic basins with location of Tr-1 and DV-1 drillholes; simplified lithostratigraphic scheme of the Stephanian of Western and Central Bohemian basins. Abbreviations: J.M. - Jelenice Member, H.M. - Hředle Member, L.M. - Ledce Member, O.M. - Otruby Member.

members correspond to facies associations representing offshore-lacustrine and prodelta-lacustrine depositional environments (Skoček 1990).

Fine grain-size, organic-carbon enrichment and undisturbed lamination are the main features of the offshorelacustrine Mšec Member which consist of: i) nearly massive claystones, ii) thinly laminated clayey siltstones with typical dark-light couplet lamination, and rarely of iii) thin layers of fine- to medium-grained sandstones with erosional bases and well-developed gradation (Fig. 2). Up to several centimetres thick massive or laminated siderite layers rich in faunal debris occur episodically, whitish volcanic ash layers ranging from coarse-sand to clay in grainsize were also observed in the basinal lake area ( $\mathrm{Tr}-1$ core). Total organic carbon content (TOC) of the claystones varies considerably, between $2-5 \%$ and can reach up to $10 \%$ (Skoček 1990). It consists mainly of algal material and rare terrestrial flora detritus. Coprolites, fish scales, bones and skeletons are relatively common in contrast to terrestrial flora which is more abundant in clayey siltstones with typical couplet-lamination (Figs 2J, 6).

The prodelta-lacustrine Hředle Member differs from the offshore-lacustrine Mšec Member by its rapid alterna- tion of facies with various grain-sizes. The omnipresent dispersed organic matter consists of large fragments (up to several $\mathrm{cm}$ ) of humified or oxidised floral debris, including floral fragments such as stems, tissues and leaves. The prodelta-lacustrine facies association consists of: i) grey to dark grey horizontally laminated fine-sandy siltstones usually rich in dispersed organic matter; ii) pale grey to pale orange layers of fine- to medium-grained sandstones with sharp bases and well developed gradation, and iii) thick, pale grey units of fine to medium-grained horizontally to low-angle cross stratified or rippled sandstones. In addition, the short intervals of clayey siltstones with couplet lamination can also occur locally.

The thickness of the offshore-lacustrine facies association, focused on in this study, varies between 5 to $35 \mathrm{~m}$; however, it is stable over most of the basin area, varying between 20 to 25 m (Skoček 1968, 1990). The basal contact is usually sharp (Tr-1) or gradational (DV-1) and can be interpreted in sequence-stratigraphic terminology as a prominent flooding surface. The transition to the overlying prodelta-lacustrine facies association tends to be gradational. The number of clayey rip-up clasts (Figure 2D) in the basal layers of sandstones in the overlaying facies 
association (Skoček 1990, Pešek 1994) indicates, however, pronounced erosion and redeposition of the offshore-lacustrine deposits linked with delta progradation. The thickness of the prodelta-lacustrine facies association is highly variable reaching up to $90 \mathrm{~m}$ according to its palaeogeographic position (Pešek 1994). If the offshorelacustrine facies association is completely absent, then it forms the whole Malesice Member lacustrine unit.

The stratigraphic distribution and relative proportion of facies in the offshore-lacustrine facies association slightly differ in the two studied cores due to their differing palaeogeographic positions. Dark grey claystones occur at the base, however, their thickness varies laterally and it is almost doubled in the basinal lake setting ( $\mathrm{Tr}-1$ core). The most common facies in both cores is clayey siltstone with couplet lamination, however, the couplet thickness varies over a much wider range in the DV- 1 core $(0.3 \mathrm{~mm}-8 \mathrm{~cm})$ than in the Tr-1 core $(0.2 \mathrm{~mm}-2 \mathrm{~cm})$. Thin layers of graded sandstones are quite exceptional in the $\mathrm{Tr}-1$ core, while their number and thickness are greater in the DV-1 core indicating its more proximal position to the former lake margins. This interpretation is also supported by an order of magnitude increase in the number of distinct siderite laminae indicating a better-oxygenated environment in the marginal lacustrine setting (DV-1 core).

\section{Methods}

\section{Coring and lithology}

The two shallow drillholes, $80 \mathrm{~km}$ apart were made in the lacustrine sequence, the first one in central Bohemia in the vicinity of the city of Slaný ( $\operatorname{Tr}-1$ well), and the second one in western Bohemia in the vicinity of town Plzeň (DV-1 well, Fig. 1). Contrary to the Tr-1 well (40 m deep) situated in the central part of the former lake basin, the DV-1 well (60 $\mathrm{m}$ deep) was situated in the southwest basin area, which was suggested as being a more proximal lacustrine setting (Skoček 1968, 1990; Pešek 1994).

The acquired cores were halved. One half of the cores were polished and photographed. The second half of the cores were subjected to detailed description, sampled for thin-sections, chemical and organic matter analyses, and finally used for palaeontological examination. Several geophysical logs were acquired from the drill holes using a Mineral Logging System device (Penetra, s.r.o., Czech Republic). The most important logs were microresistivity and magnetic susceptibility with a $2 \mathrm{~cm}$ electrode distance. A $\gamma$-ray $\log$ was acquired with distance of $0.33 \mathrm{~m}$ between the source and the neutron radiation detector.

X-ray fluorescence analysis (XRF) of powdered sediments was performed with a PANalytical MiniPal4.0 spectrometer with $\mathrm{Rh}$ tube and energy dispersive detector. The results were not recalculated via calibration to elemental composition but the element ratios were used as measures of compositional changes within the sediments. Samples for carbonate stable isotope determination were pulverized in an agate mortar and treated in a vacuum with $100 \% \mathrm{H}_{3} \mathrm{PO}_{4}$, at $25^{\circ} \mathrm{C}$ for calcite (McCrea 1950) and at $100^{\circ} \mathrm{C}$ for siderite (Rosenbaum \& Sheppard 1986). The measurement of $\mathrm{C}$ and $\mathrm{O}$ isotopic composition of the resultant $\mathrm{CO}_{2}$ gas was performed using a Finningan MAT 251 mass spectrometer in the Laboratories of the Czech Geological Survey in Prague. The acquired $\delta^{18} \mathrm{O}$ values for siderite decomposed at $100{ }^{\circ} \mathrm{C}$, and were corrected for the different acid fractionation factor during $\mathrm{CO}_{2}$ preparation by the addition of $+1.44 \%$ (Rosenbaum \& Sheppard 1986). Results are displayed using the normal $\delta$ notation agains and the international V-PDB standard. Overall analytical uncertainty was $\pm 0.1 \%$ for both $\delta^{13} \mathrm{C}$ and $\delta^{18} \mathrm{O}$ values.

\section{Study of thin and polished sections}

Uncovered and covered thin sections were studied under plane-polarized transmission light using a Nikon Eclipse $80 \mathrm{i}$ optical microscope. The composition and optical properties of dispersed organic particles were examined using a UMSP 30 Petro Opton-Zeiss microscope under reflected monochromatic light and UV excitation (Hg lamp and filter reflector FL05) and Nikon ECLIPSE ME600 with image analysis system LUCIA 4.22. Random reflectance values, maceral composition of vitrinite and inertinite groups, and mineral composition of samples were recorded from polished blocks using immersion objectives (20x, $40 \times, 100 \times$ magnification) in oil immersion $(\mathrm{n}=1.518)$, in

Figure 2. Typical facies of prodelta-lacustrine (A-D) and offshore-lacustrine (E-L) facies associations from both studied cores (DV-1 on the left, Tr-1 on the right), the scale bar is $2 \mathrm{~cm}$. $\bullet$ A - sandy turbidite with poorly developed grading, sharp bases and load casts. $\bullet$ B - graded sandy turbidite with upward increasing amounts and sizes of terrestrial floral debris. $\bullet$ C, D - alternation of silty and sandy layers rich in clayey rip-up clasts. $\bullet$ E - very thick couplets (subtype IIb) with occasional positive gradation in detrital half-couplet. Note siderite laminae (orange) in organic-clay half-couplets, the bleached horizons represent the coarsest - fine sandy - laminae. $\bullet \mathrm{F}$ - subtype IIb couplets with well-developed reverse grading consisting of coarsening, sharp-based very-fine sandy laminae, note also upward increasing siderite proportion in detrital half-couplets. $\bullet \mathrm{G}$, $\mathrm{H}-$ the only set of sandy turbidite layers from the offshore-lacustrine association in the basinal lake area. $\bullet$ I - very fine sandy siltstones of subtype IIb lamination with well-developed gradual transitions between couplets. $\bullet \mathrm{J}-$ typical clayey siltstone with couplet lamination subtype IIa. $\bullet \mathrm{K}$, L - organic-rich claystones of irregular lamination Type I containing common bituminite, pyrite and alginite. 
Richard Lojka et al. • Lacustrine couplet-lamination: evidence for Late Pennsylvanian seasonality
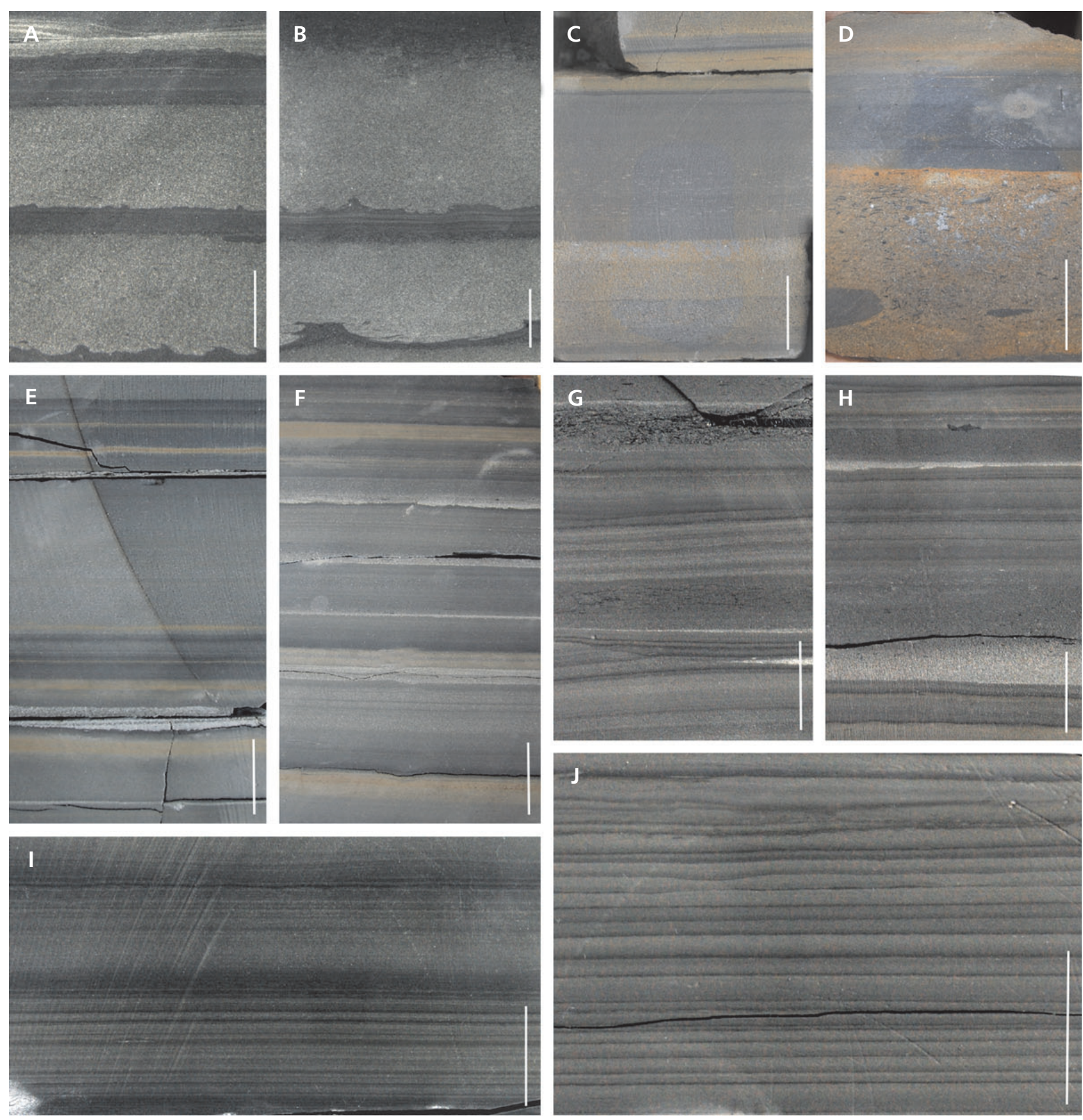

K

L 


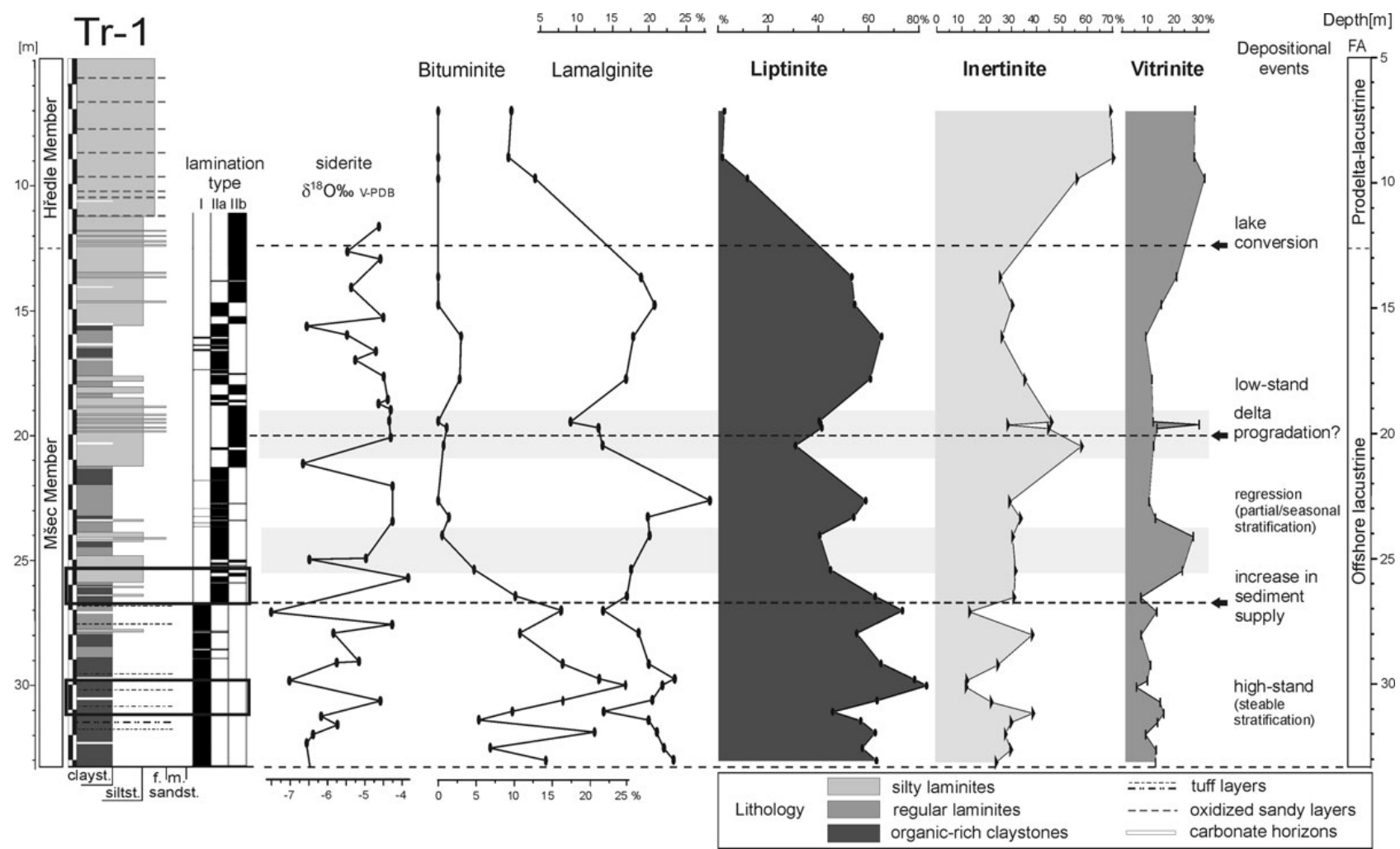

Figure 3. Tr-1 log with lamination types, siderite oxygen isotope and selected dispersed organic maceral composition and interpreted events in lake development. Frames in the sedimentary log mark intervals examined for periodicity of lamination.

monochromatic light $(\lambda=546 \mathrm{~nm})$ according to ISO 7404 (2009) and ICCP (1998 and 2001). The maceral composition of the liptinite group was determined using the same equipment in the fluorescence mode following the widely accepted methodology (Hutton 1987a, Kalkreuth \& Macauley 1989, Taylor et al. 1998). Proportions and stratigraphic distribution of individual macerals in both cores are summarized in electronical Appendices 2 and 3, definitions of maceral groups and individual macerals are given in Appendix 1. Vertical trends in the proportions of maceral groups and important macerals in the two cores are shown in Figs 3 and 4.

\section{Time-series analysis}

Two intervals from the basinal lake area (Tr-1, Fig. 3), were examined for the occurrence of periodic changes in lithology and couplet thickness. The examined intervals were carefully selected to cover all of the visually observed lamination patterns. As the laminated intervals exhibit a strong correlation between sediment colour and lithology $($ white $=$ silt, black = organic-rich mud), the first time series set used greyscale densitometry from high-resolution photographs as a proxy for lithology and grain size. The second time series set was constructed from couplet thicknesses.
The combination of two different time series sets was chosen because each method of time-series construction has specific weaknesses that complicate or prevent signal interpretation if used alone. For example, the couplet-thickness series lacks any information on lithological changes that are not expressed in thickness variation. Therefore, harmonic oscillations in lithology and sedimentation rate on the scale of the individual couplets must be examined using a greyscale-densitometry series. On the other hand, the greyscale spectrum fails to fully describe magnitude variations in the depositional force on couplet-lamination because these variations are manifested largely by changes in sedimentation rate of the silt fraction, i.e., thickness of silt lamina, with little or no shift towards a brighter colour. Being a depth-domain series, the greyscale-densitometry is affected by power leakage due to frequency modulation imposed by changing couplet thicknesses. The use of both time series should increase the chances that a real signal is identified.

Spectral estimates presented in this paper are based on a recent modification of the Multi-taper method (MTM) spectral analysis (Thomson 1982), which combines detection of harmonic signals with a criterion for detecting quasi-oscillatory signals which may exhibit phase and amplitude modulation (Mann \& Lees 1996). This approach appears most suitable for the detection of climatic cycles, which are often associated with significant modulation of 


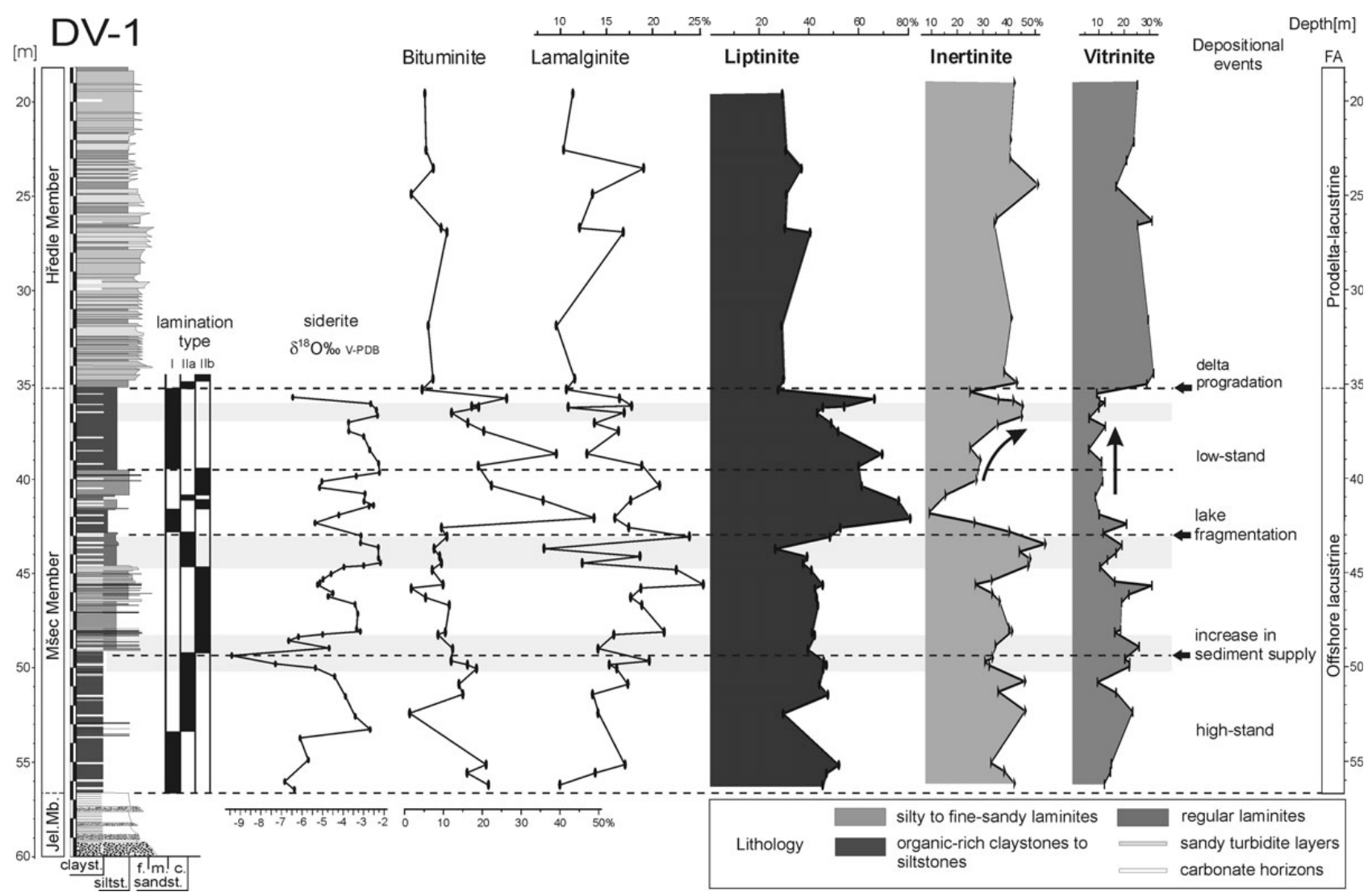

Figure 4. DV-1 log with lamination types, siderite oxygen isotope and selected dispersed organic maceral composition and interpreted events in lake development. Note increasing proportion of inertinite during low-stand, while the vitrinite remains constantly low (arrows).

amplitudes and frequencies. Two or three $3 \pi$ tapers provided suitable resolution without significant spectral leakage.

Significance levels were determined relative to the analytical red noise spectrum (Mann \& Lees 1996). The red noise null hypothesis represents a combination of random processes and spectral leakage towards low frequencies, which could be due to sampling bias and/or natural processes in the depositional and climate systems. Measurement of couplet thicknesses employed in this study should not support any red-noise deformation because measurements of the successive couplets are independent from each other. However, it is assumed that red noise is a suitable representation of stochastic processes in depositional and climate systems, because the intrinsic inertia of these systems generates a leakage of power toward lower frequencies even in the absence of any signals (Hasselmann 1976, Weedon 2003).

To test our approach to signal detection, we constructed a set of simple numerical models simulating the interplay of random and harmonic signatures in couplet thicknesses based on a linear combination of relatively high-amplitude random series and relatively low-amplitude sinusoidal series. In these models both MTM and Singular Spectrum Analysis often underestimated noise levels in the high- frequency portion of the power spectrum. Both methods assigned high significance (up to $99.9 \%$ ) to certain random signatures mostly between 0.3 cycle/couplet and the Nyquist frequency, thus generating false estimates of couplet bundling (typically $1: 2$ to $1: 3$ ). Such random signatures can mimic or mask short-term climatic signals, e.g., the Quasi-Biennial Oscillation (Baldwin et al. 2001). Due to our inability to distinguish signal from noise in this part of the spectrum, high-frequency spectral maxima in couplet thicknesses are not further discussed in this paper. Similar spurious signals occasionally formed at all frequencies, in accordance with the theory ( $c f$. Thomson 1982, Mann \& Lees 1996). Therefore, we chose a conservative approach to signal interpretation based on the following criteria: (i) a significant ( $>95 \%$ ) spectral maximum must occur in both the couplet-thickness and greyscaledensitometry series and (ii) the signal must accommodate at least $15 \%$ of the total variance.

Piecewise linear interpolation was used to resample the greyscale series in 0.1 and $1 \mathrm{~mm}$ steps in order to more clearly identify both high-frequency (couplet-scale) cyclicity and relatively low frequency (cm-scale) features. If the lowest frequency spectral maximum in the greyscale series exceeded a $40 \%$ variance contribution, it was filtered-out 
in order to highlight small-scale ( $\mathrm{mm}$ to $\mathrm{cm}$ ), low-amplitude features. The removed components include (i) relatively long-term lithological changes whose potential periodicity cannot be evaluated in the limited thickness of the study intervals, and (ii) possible sampling bias (e.g., due to differences in moisture contents).

Analyseries software, v. 2.0.3 for MacOSX (Paillard et al. 1996) and kSpectra, v. 2.18 for MacOSX (SpectraWorks commercial software) were used for the spectral estimation. Variance contributions were calculated using the Singular Spectrum Analysis tool implemented in the kSpectra software. Complex demodulation and coherence tests were performed using Arand software (Howell 2001).

\section{Results}

\section{Lamination structure}

Two basic types of lamination were recognized in the offshore-lacustrine facies association reflecting two main lithofacies in both cores. Claystones have usually poorly developed sub-milimetre to millimetre-scale lamination (Type I), while the clayey (Tr-1) to sandy (DV-1) siltstones show regular lamination (Type II) formed mostly of reverse-graded couplets. The lake nearshore depositional setting (DV-1) produced coarser and typically by an order of magnitude thicker couplets than the basinal setting (Tr-1). The prevailing reduced supply of silt-grained clastics produced thinly developed couplets in the basinal lake area allowing construction of a well-defined time series.

\section{Irregular lamination (Type I)}

The dark grey organic-rich claystones are either thinly laminated by sub-millimetre thick more or less continuous silt laminae, or almost massive due to the scarcity of pale detrital laminae. The massive areas of claystones consist of several millimetre thick homogeneous (massive) laminae which do not show any vertical trends in grain-size. Micro-scale horizontal lamination consists of lamalginitebituminite fibres dispersed in a clayey matrix (Fig. 5). Only subtle quantitative changes in dispersed organic matter and proportion of silt define the individual laminae. The boundary surfaces between homogeneous laminae are usually emphasized by discontinuous sub-millimetre scale silt and/or siderite lamina forming together with an underlying homogeneous lamina, "homogeneous couplet" (subtype Ia lamination, Fig. 5). A wide range of thicknesses of these couplets (1.5-12 mm) creates an apparently irregular lamination pattern. Discontinuous silt laminae tend to form continuous clusters consisting of several alternating sub-millimetre scale silt and liptinite lenses forming very thinly developed silt-organic couplets. Silt clusters vary in thickness usually from 0.5 to $5 \mathrm{~mm}$. These tiny clusters alternate with homogeneous couplets (Fig. 5A-C) or form several decimetre thick intervals of "cluster lamination" (subtype Ib). This type of lamination may represent a condensed equivalent of the regular couplets of Type II lamination (Fig. 13), the prevailing type of lamination in the studied lacustrine series.

Type I lamination in both cores is typical for organicrich claystones deposited mainly during the initial lake stage, and locally (DV-1) also at a higher stratigraphic level in the clayey siltstones underlying the prodelta-lacustrine facies association. In the offshore lacustrine setting (Tr-1), centimetre-thick intervals of Type I lamination still appear episodically within the set of regular couplets of Type II lamination.

Organic matter composition. - The liptinite group of macerals, mainly alginite, liptodetrinite, and bituminite, dominate the dispersed organic matter in claystones. Alginite consists of lamalginite and subordinate larger fragments of telalginite, which are almost absent in the marginal lake area (DV-1). Finely laminar lamalginite is concentrated into homogeneous laminae and forms irregular colonies and layers; it usually has weak to moderate fluorescence under UV light and a distinct lamellar shape (Fig. 7A, B). Contrarily to telalginite, which is derived from colonial or thick-walled unicellular algae such as Botryococcus or Tasmanites, lamalginite is derived from small, unicellular or thin-walled, colonial plankton or benthic algae (Teichmüller \& Ottenjan 1977, Hutton 1987b, Taylor et al. 1998, Ratanasthien et al. 1999) living in photic zones of shallow lake areas.

Bituminite displays a granular texture and occurs as an irregular mesh-like network or microlaminae, with a thickness up to $100 \mu \mathrm{m}$ (Fig. 7A, C). There are significant differences in the distribution and quality of bituminite between marginal and basinal lacustrine settings. The basinal lake area (Tr-1) contain the highest proportion of bituminite (up to $25 \mathrm{vol} \%$ ) in the lower part of the offshore-lacustrine facies association, two major populations of bituminite were recognized based on fluorescence shade (Fig. 7F) and total reflectance: the prevailing weakly brown fluorescing bituminite with total reflectance $\mathrm{R}_{\mathrm{B}}=0.20-0.40 \%$ and a minor non-fluorescing bituminite with reflectance $\mathrm{R}_{\mathrm{B}}=$ $0.45-0.60 \%$. The proportion of bituminite decreases rapidly as facies change to rhytmically laminated clayey-siltstones. In the lake marginal area (DV-1), the low proportion $(\sim 10 \mathrm{vol} \%)$ of poorly mature, non-fluorescing bituminite with low reflectance is typical for most of the offshore-lacustrine facies association. Its proportion sharply increases (up to $50 \mathrm{vol} \%$ ) in the clayey interval underlying the prodelta-lacustrine facies association (Fig. 4). Liptodetrinite, with particle size less than $10 \mu \mathrm{m}$, is very 

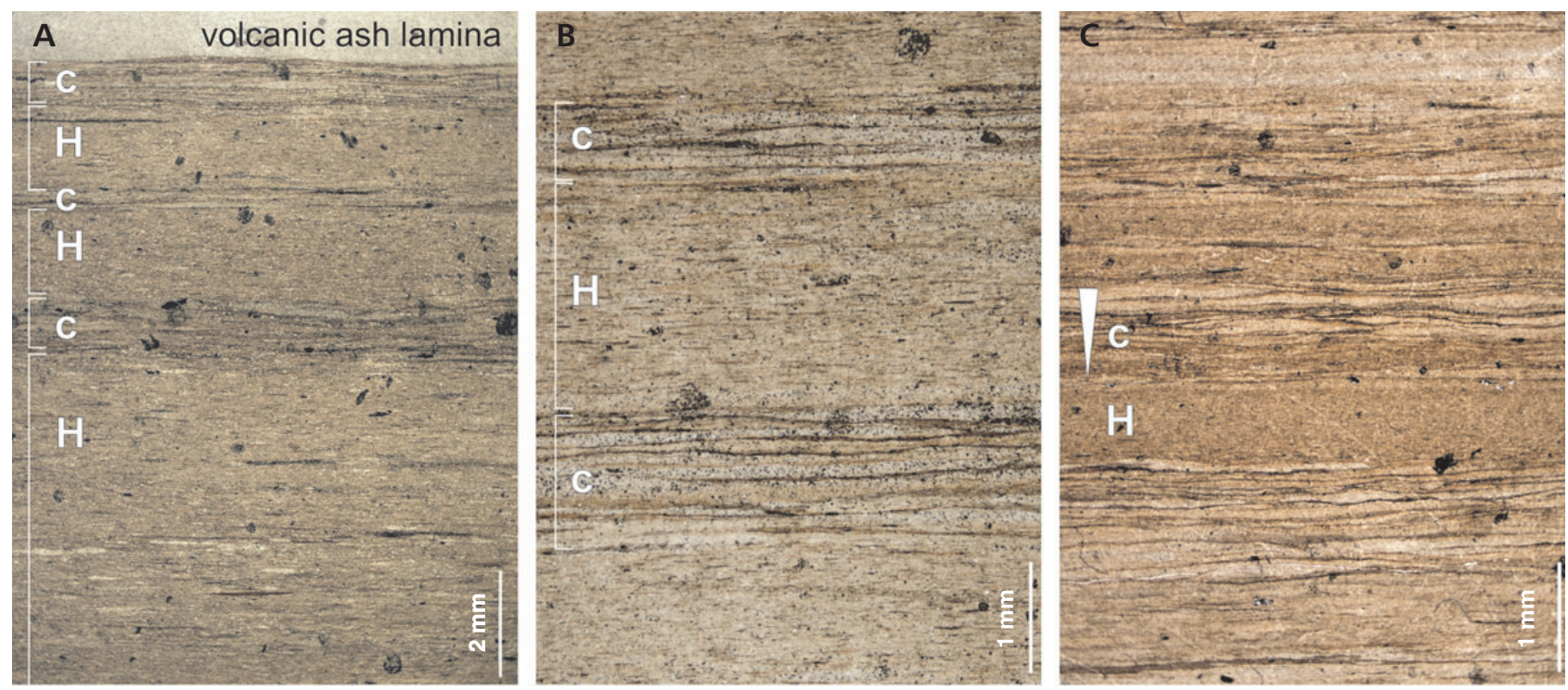

H.
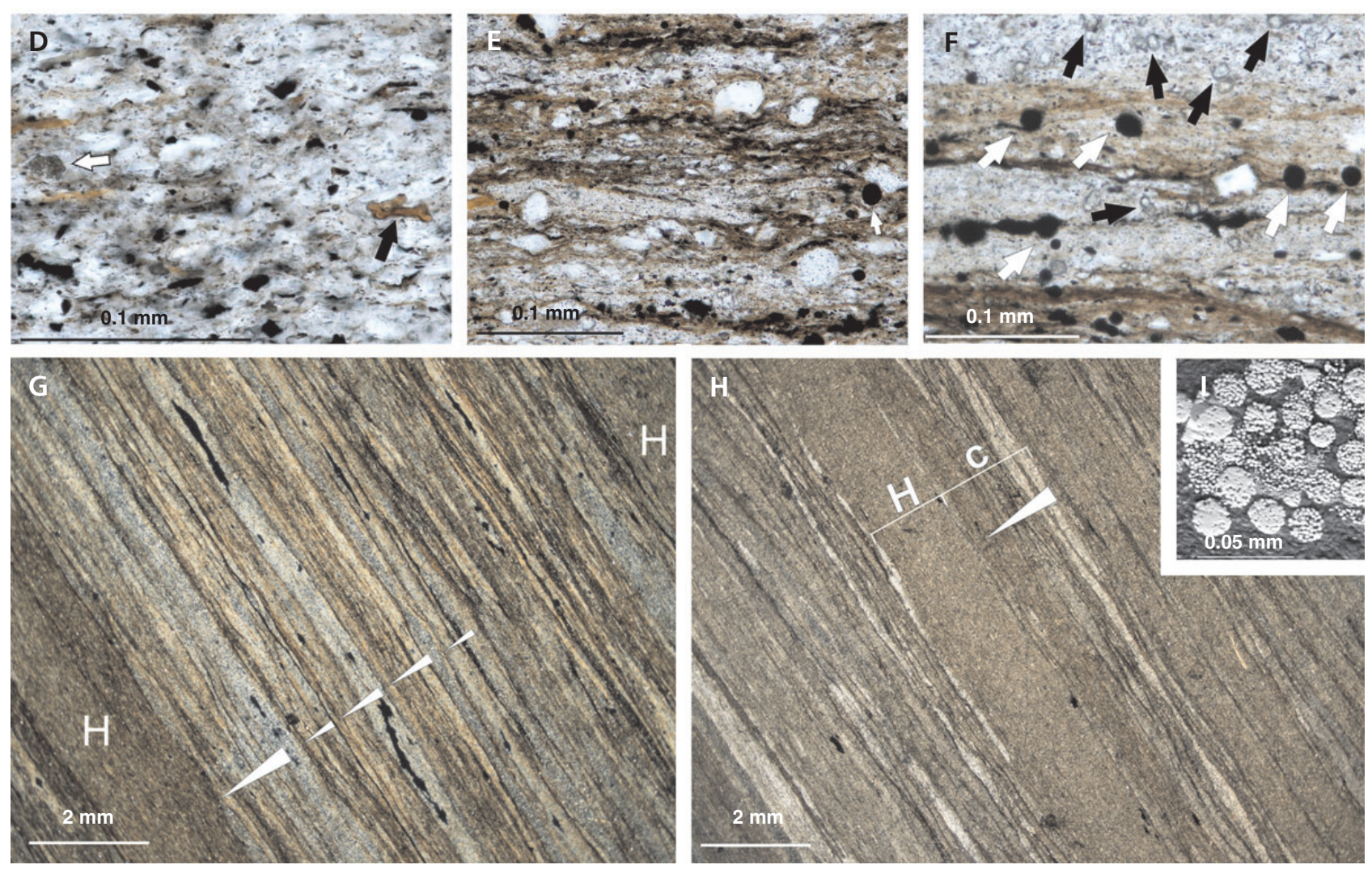

Figure 5. Type I lamination. $\bullet$ A-C - examples of lamination subtype Ia with prevailing homogeneous laminae (H) interbedded by silty clusters (c), local inverse grading in clusters (parallel nicols, PN). $\bullet \mathrm{D}$ - detail of thin silt lenses with prevailing terrestrial plant debris (opaque grains), black arrow indicates pollen grain and white arrow siderite nodules $(\mathrm{PN}) \cdot \bullet \mathrm{E}$ - detail of silt cluster with alternating silt and alginite laminae $(\mathrm{PN}) \cdot \bullet \mathrm{F}$ - detail of silt cluster (PN), the dark arrows indicate dispersed siderite ribbons while the white arrows mark balls of framboidal pyrite composed of tens of very fine framboides (i). $\bullet \mathrm{G}, \mathrm{H}$ - cluster lamination subtype $\mathrm{Ib}$, note discontinuity of silt laminae and locally apparent coarsening trend in clusters (crossed nicols, $\mathrm{XN}$ ).

common, it has yellow-orange fluorescence and forms a part of the lamalginite-bitumnite microlaminae. Sporinite is present in minor amounts $(<5 \mathrm{vol} \%)$; resinite, cutinite, and zooclasts, particularly coprolites and fish scales occur irregularly as accesories.
The proportion of inertinite macerals significantly varies in offshore (12.2-38.5 vol\%) as well as in nearshore lacustrine settings (9-46.2 vol\%). In contrast to the offshore area, where the proportions of the main types of inertinite macerals such as fusinite, semifusinite and 
inertodetrinite are relatively well-balanced, in the marginal area inertodetrinite prevails (up to 33 vol\%). The proportions of vitrinite macerals, a humified terrestrial plant debris, vary around $\sim 10$ vol\%. Both inertinite and vitrinite macerals occur preferentially in silt laminae and clusters, while the liptinite macerals occur usually in homogeneous laminae and liptinite lenses.

Mineral composition. - The detrital composition of claystones depends on the stratigraphic and, less significantly, on the palaeogeographic position. It is also affected by the varying proportion of silt. Clay mineral assemblage is dominated by kaolinite, less common is illite-muscovite and only minor amounts of illite/smectite $(\sim 5 \%)$. The kaolinite proportion varies between 20 and $35 \%$ and tends to decreases upwards, while the illite proportion tends to increases upwards (Lojka et al. 2009). This trend results in a balanced proportion of kaolinite to illite-muscovite in silty claystones at a higher stratigraphic level in the marginal lacustrine setting (DV-1), while kaolinite still slightly prevails in the basinal lacustrine setting. Liptinite laminae in clusters and also homogeneous laminae contain a number of pyrite framboids $(\sim 5 \mu \mathrm{m})$ arranged as circular colonies (Fig. 5F, I) altering the organic macerals. Quartz, potassium feldspars and muscovite dominate the silt material. Silt laminae are often enriched by fine siderite crystallites that are randomly dispersed, also in homogeneous couplets (Fig. 5D). Silt laminae and lenses in clusters tend to differ in grain-size and composition consisting of alternating quartz, mica and clay-organic laminae arranged in a roughly coarsening-up trend (Fig. 5G, H).

\section{Couplet lamination (subtype lla)}

Rhythmically alternating dark grey (organic-clay) and pale (silt-very fine sand) laminae are usually linked to continuous transitions to form coarsening-up couplets (Type II lamination). The couplets may form (i) millimetre-scale lamination in clayey siltstones (subtype IIa lamination) or (ii) composite centimetre-scale lamination in sandy siltstones (subtype IIb lamination; see below) consisting of several laminae with varying grain-size and siderite proportions. A continuous series of thinly developed couplets in clayey siltstones (subtype IIa) dominates the basinal lacustrine sedimentation (Fig. 3), while in the marginal lake area (Fig. 4) it forms only discrete intervals within the prevailing composite couplet lamination (subtype IIb).

Lamination couplets vary significantly in thickness (0.2-8.5 mm), mostly depending on the thickness variation of detrital half-couplets. The thickness of organic-clay half-couplets ranges from 0.1 to $2 \mathrm{~mm}$, most commonly about $0.2-0.5 \mathrm{~mm}$. Organic-clay half-couplets are locally anastomosing and usually have sharp and wavy basal sur- faces (Fig. 6E), occasionally interrupted by several millimetre high inclined burrows (Fig. 6C). The pale silt half-couplets either gradually rise from the organic-clay half-couplets with an increasing silt proportion or sharply overlay the dark half-couplets usually with no marks of erosion. More significant erosion with considerably high (several $\mathrm{mm}$ ) erosional relief is located on the base of the couplets, on the sharp basal surfaces of the organic-clay half-couplets (Fig. 6D). The grain-size of silt half-couplets tends to continuously increase upwards to form reversegraded couplets. Well-developed couplets are topped by thin, sharp-based, coarse-silt to very fine-sand laminae containing a large amount of the coarsest (up to $150 \mu \mathrm{m}$ ) terrestrial plant debris (Fig. 6F). Detrital laminae usually dominate the couplets and locally even erode the underlying organic-clay lamina (Fig. 6G), which results in coalescence and amalgamation of silt half-couplets.

Organic matter composition. - The half-couplets significantly differ in composition of the dispersed organic macerals. The organic-clay half-couplets consist dominantly of liptodetrinite and finely laminar lamalginite forming thin layers or irregular colonies. Bituminite is only accesorial or completely absent. Lamalginite and liptodetrinite, however, are also occasionally dispersed in the silt half-couplets which are dominated by oxidised and humified terrestrial plant debris, represented by inertinite (28.6-57.6 vol\%) and vitrinite $(6.3-28 \mathrm{vol} \%)$ macerals. Inertinite macerals consist namely of inertodetrinite, fusinite and semifusinite and are easily identified due to their higher reflectance and distinct particle morphology. The proportion of the most common inertodetrinite with a particle size less than $10 \mu \mathrm{m}$ (Fig. 7D), varies greatly between 10.5 and 28.8 vol\%, and does not show any correlation with other macerals. Fusinite particles are characterized by a well-preserved original cellular structure (Fig. 7G, H) and high reflectance ranging from $1.10 \% \mathrm{R}$ to $2.90 \% \mathrm{R}_{\mathrm{I}}$. Semifusinite particles show intermediate reflectance varying between $0.80 \% \mathrm{R}$ and $1.30 \% \mathrm{R}_{\mathrm{I}}$ and a structure between telovitrinite and fusinite with partly visible cell tissues (Fig. 7I). Peaks in both these associated macerals in the basinal lacustrine setting (Tr-1) occur within the amalgamated silt couplets associated with sets of fine sandy turbidite laminae (Figs 2, 3).

The proportion of vitrinite macerals is relatively low compared to liptinite and inertinite. Humified organic debris consists mainly of collotelinite and vitrodetrinite, with minor components being gelovitrinite, corpogelinite, telinite and gelinite macerals. The most common vitrodetrinite occurs as dispersed particles of humified and/or non-humified cellular tissues of herbaceous and arborescent plants of varying shape, and size less than $10 \mu \mathrm{m}$. The silt half-couplets as well as composite couplets locally contain elongated and articulated strips (tens to hundreds of $\mu \mathrm{m}$ ) of amorphous vitrinite with regular seg- 

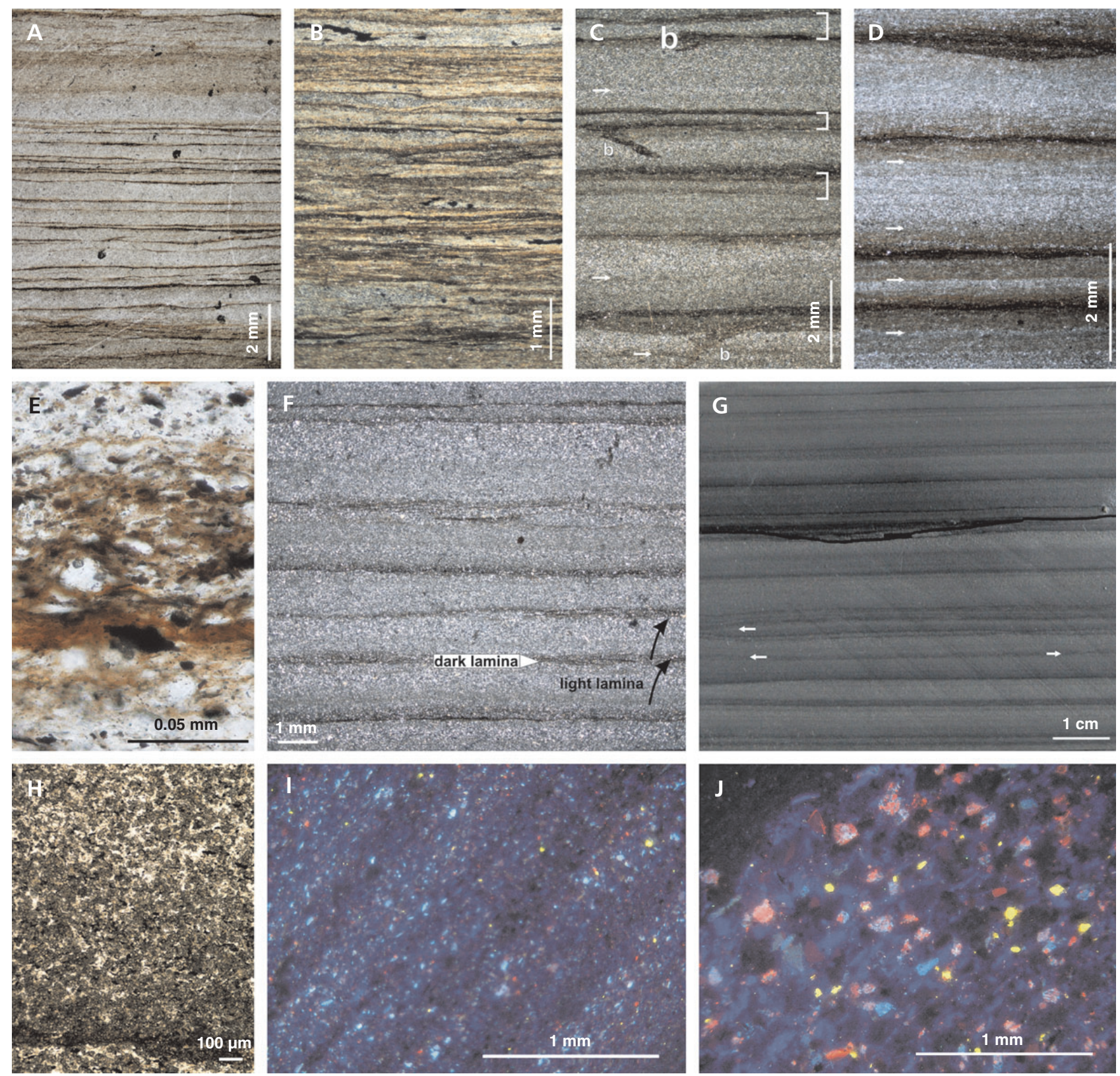

Figure 6. Type II lamination. • A - silt laminae dominated couplets, note apparent discontinuity of organic half-couplets (PN). $\bullet$ B - cluster lamination subtype $\mathrm{Ib}$ with prevailing liptinite strips and discontinuous silt laminae $(\mathrm{XN})$, possible condensed equivalent of couplet lamination subtype Iia. - C - laminae couplets with well-defined (arrows) coarser (upper) parts of the detrital half-couplets, note local twinning of organic half-couplets and also millimetre thick inclined burrows (b) in several couplets $(\mathrm{XN}) \cdot \bullet \mathrm{D}$ - well-developed couplets with mostly sharp or gradational bases of organic half-couplets, note considerable relief of organic half-couplet of the top most couplet, brown rims along organic half-couplets correspond to siderite admixture (arrows, $\mathrm{XN}$ ). $\bullet \mathrm{E}$ - detail of sharp-based organic half-couplet with light brown alginite (PN). $\bullet \mathrm{F}$ - well-developed coarsening up (arrows) couplets of subtype IIa lamination $(\mathrm{XN}) \cdot \bullet \mathrm{G}$ - lamination couplets dominated by silt half-couplets suppressing organic half-couplets, incipient couplet amalgamation is indicated by arrows. $-\mathrm{H}$ - detail of siderite-rich couplet, note gradual decrease of siderite with increasing distance from organic lamina (PN). - I - compositional variations in couplets, note omnipresent kaolinite matrix (dark-blue background) and number of angular potassium feldspar grains (light-blue) in silty half-couplets (cathodoluminiscence, CL). $\bullet \mathrm{J}$ - detail of silt half-couplet with volcanic quartz grains (purple-red), potasium feldspars (light-blue) and kaolinite matrix (CL).

mentation (Fig. 7I). Robl et al. (1992) described an elongated form of vitrinite from the Mississippian black shale in east-central Kentucky as possible remnants of aquatic macrophyta. These possible relict particles of aquatic macrophyta occur in both cores, reaching several milimetres in length in thin sections.

Reflectance of vitrinite particles varies between 0.6 and $0.71 \% \mathrm{R}_{\mathrm{r}}$ within the offshore-lacustrine facies association. 
Table 1. Summary of mineral and chemical composition of both half-couplets in couplet lamination subtype IIa.

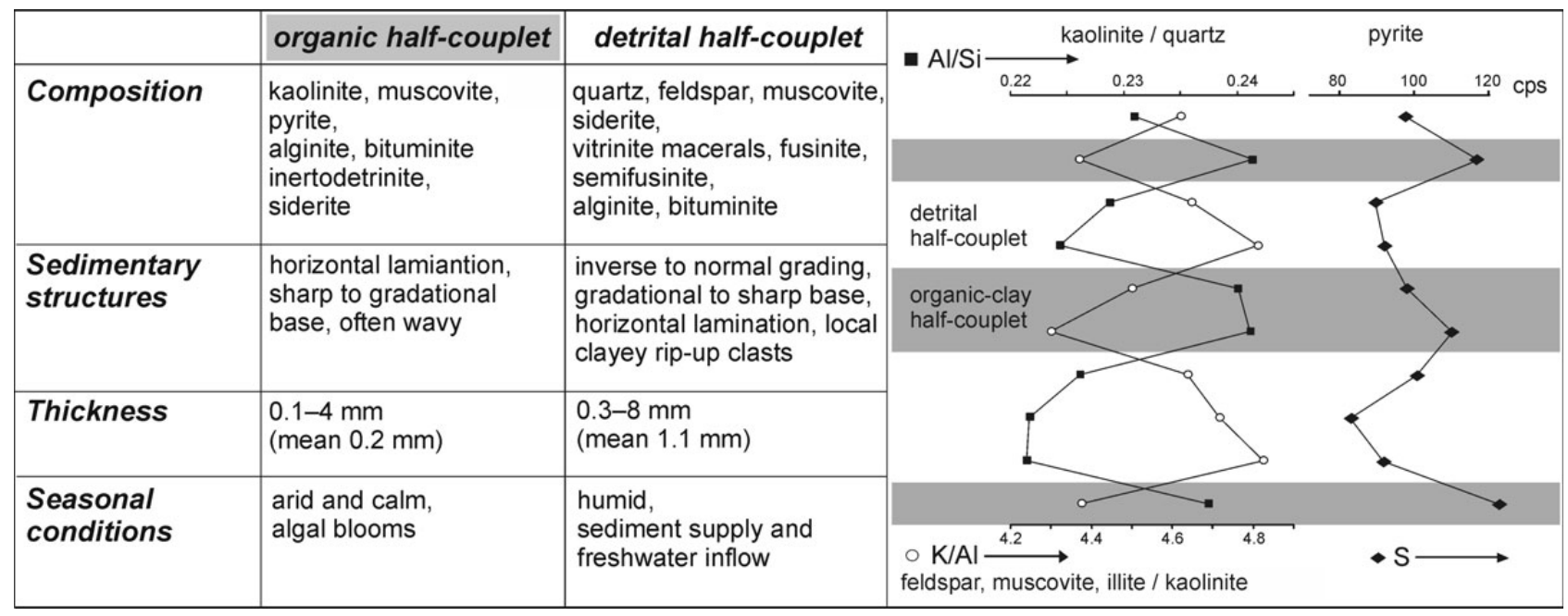

Higher reflectance vitrinite $\left(>0.75 \% \mathrm{R}_{\mathrm{r}}\right)$ is typical for liptinite-poor sandstones of the prodelta-lacustrine facies association. Notabely lowered values may result in a hydrogen-rich environment and impregnation by substances derived from associated lipoid components of alginite and bituminite (Hutton \& Cook 1980, Kalkreuth \& Macauley 1989, Robl et al. 1992, Gentzis \& Goodarzi 1994).

Mineral composition. - The detrital material of clayey siltstones consists of quartz, potassium feldspar, muscovite, illite, kaolinite, illite/smectite and accessory heavy minerals such as apatite and zircon. Dark $\mathrm{Fe}^{2+}$ silicates are absent except for rare grains of altered biotite in very fine sandy laminae. The mineral composition differs from that of claystones (Type I lamination) especially in the higher proportion of dispersed siderite crystallites and K-bearing detrital minerals (feldspar and muscovite), and lowered proportion of kaolinite. Several types of quartz grains of different origins are present according to CL imaging. Most of them seem to be from a low-temperature origin (e.g., sedimentary) with dark brownish to purplish CL. There are also quartz grains of volcanic origin which have typical reddish CL (Götze 2000, Götze \& Zimmerle 2000), much brighter than the low-temperature quartz grains (Fig. 6I, J). The overwhelming majority of grains are angular with sharp edges. Potassium feldspars (with very intensive bright-blue stable CL) are also markedly angular, with very sharp edges, indicating short transport implying a rather low ratio of drainage basin to lake area.

The observed compositional and structural differences of half-couplets are listed in Table 1. The mineral composition differs namely in the proportions of the individual components. The organic-clay half-couplets are dominated by kaolinite as revealed by the low $\mathrm{K} / \mathrm{Al}$ ratio. Pyrite framboids replacing organic macerals are responsible for the increased proportion of sulphur in the organic-clay half-couplets. The detrital half-couplets consist of siltsized quartz, feldspars, and abundant muscovite as indicated by the elevated K/Al ratio. Fine siderite crystallites usually concentrate in silt half-couplets but usually close to the contact with organic half-couplets (Fig. 6H).

\section{Composite couplet lamination (subtype IIb)}

Subtype IIb lamination (Fig. 2) differs significantly from subtype IIa lamination by the increased thickness and grain-size of the couplet components. This type of lamination is restricted to the marginal lake area (DV-1); only centimetre thick intervals comprising a pair of composite couplets were recognized in the basinal lacustrine setting in association with amalgamated silty couplets and fine sandy turbidites or just below the transition to the overlying prodelta-lacustrine facies association. The organic halfcouplets are generally silty and poorly developed, compared to the couplets thickness. They have gradational or sharp bases and tops and usually contain a pair of siderite laminae. Detrital half-couplets are usually formed by a 1 to $7 \mathrm{~cm}$ thick coarse silt to very fine sandy layer with horizontal lamination defined by subtle grain-size variations forming several discrete fine-sandy laminae with sharp bases and welldeveloped gradations (Fig. 2). This set of thin, very fine sandy laminae tend to coarsen upwards producing a stepwise coarsening-up trend within the couplet (Fig. 13). In contrast, a rare upward fining trend was also observed within well-developed detrital half-couplets (Fig. 2E). In addition to the described grain-size complexity, there are also significant variations in proportion of fine siderite crystallites which may be found concetrated as discrete laminae within the couplets. Up to $1 \mathrm{~cm}$ thick siderite laminae usually occur at the top of the couplets with the coarsest grain-size, however, they may also form thin distinct laminae in organic-clay half-couplets (Fig. 2E). 

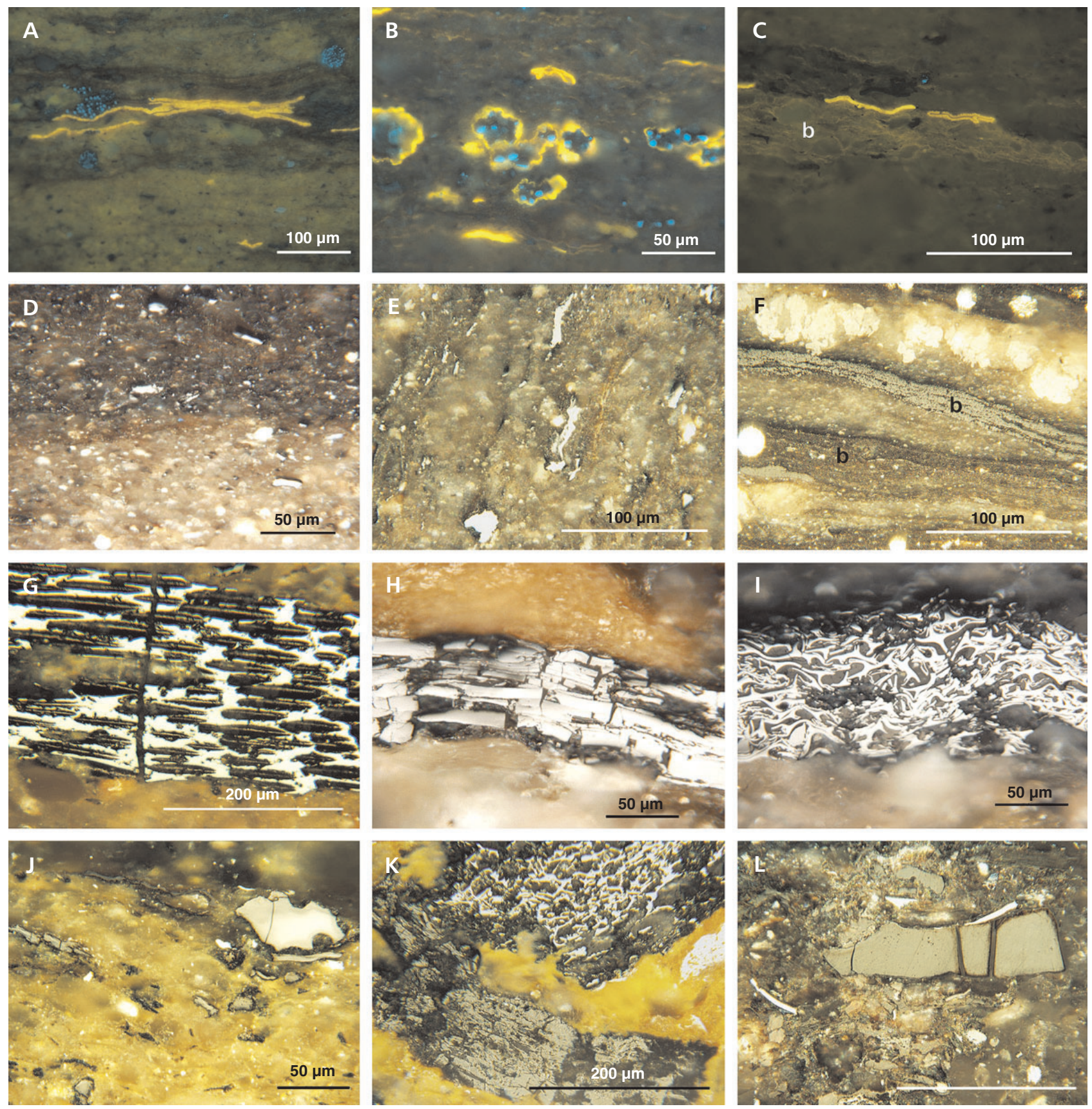

Figure 7. Morphology and composition of dispersed organic macerals. $\bullet$ A-C - autochothonous lacustrine algal bodies (lamalginite) and decomposed algal material up to bituminite in claystones, note associated very fine pyrite framboids (A) and crystal patches (C) (blue dots, fluorescent light, FL). - D - finely dispersed inertodetrinite in both half-couplets, slightly prevailing in organic-clay half-couplet (reflected light, RL). $\bullet$ - complete oxidation of algal material to intertinite (RL). $\bullet \mathrm{F}$ - both forms of bituminite (b): lamina of fine-grained high-reflectance mature bituminite overlaying the dark, poor reflectance bituminite. $\bullet \mathrm{G}, \mathrm{H}$ - typical larger fragments of high-reflected fusinite (RL). $\bullet$ I - semifusinite with partly visible cellular structure (RL). $\cdot \mathrm{J}$ - macrinite particle with oxidation rim darker in colour $(\mathrm{RL}) \cdot \bullet \mathrm{K}$ - larger semifusinite and vitrinite particles $(\mathrm{RL}) \cdot \bullet \mathrm{L}-$ fragment of segmented vitrinite resembling remnants of aquatic macrophyta.

Organic matter composition. - The composition and distribution of dispersed organic matter is quite similar to that in couplet lamination subtype IIa. The liptinite proportion varies greatly, from 26.5 to 47.8 vol\% and usually occurs in organic half-couplets. It consists namely of lamalginite, liptodetrinite and poorly mature bituminite. Inertinite and vitrinite proportions vary similarly as in the basinal lake area, from 27 to $53.9 \mathrm{vol} \%$ and 10.8 to $30.8 \mathrm{vol} \%$, respectively. As to the couplet lamination (subtype IIa), both groups of macerals normally occur in detrital half-couplets, but 

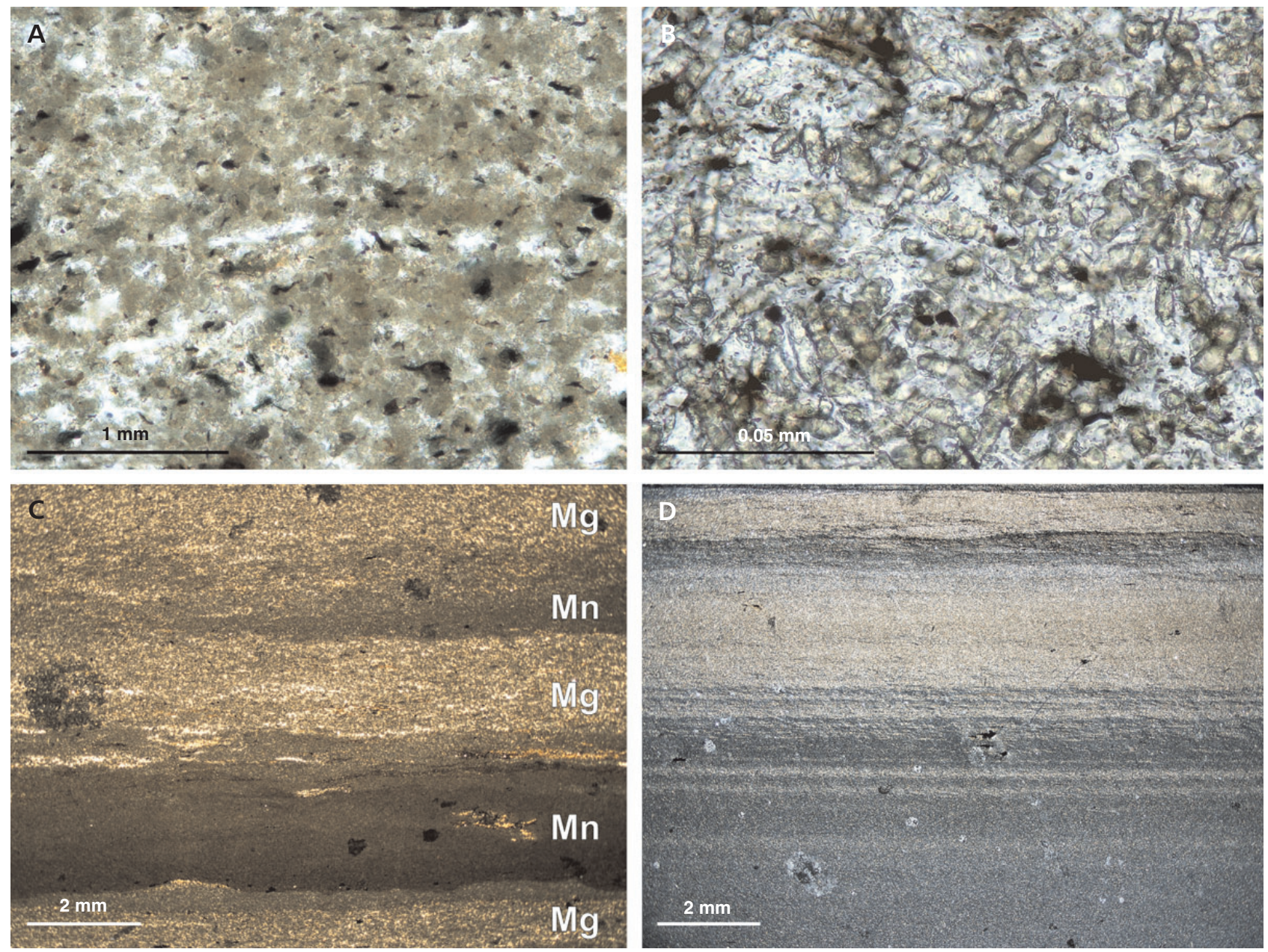

Figure 8. Morphology of siderite crystallites. • A - detail of siderite lamina rich in dispersed inertinite, note poor crystalinity and mesh-like network of siderite $(\mathrm{PN}) \cdot \bullet \mathrm{B}$ - typical morphology of siderite ribbons indicate their possible organic nucleus $(\mathrm{PN}) \cdot \bullet \mathrm{C}$ - several centimeter thick laminated siderite horizon $(\mathrm{XN})$, lamination is indicated by changes in grain-size of siderite crystallites and varying quartz admixture but mainly by changes in $\mathrm{Mn} / \mathrm{Mg}$ proportion in siderite, note also sharp erosive basal surface of fine grained Mn-rich lamina. $\bullet \mathrm{D}$ - onset of siderite lamina indicated by increasing proportion of siderite ribbons in lamination $(\mathrm{XN})$.

tend to be larger in size. Thinly developed, very fine sandy laminae with erosional bases and well-developed gradations within detrital half-couplets contain a number of large vitrinite and inertinite particles consisting mainly of collotelinite, fusinite and semifusinite.

Mineral compositon. - Mineral composition remains similar to that of couplet lamination subtype IIa, however, coarsening of grains results in a higher proportion of quartz, muscovite and feldspars. The presence of dispersed siderite is not a specific feature of composite couplets; however, when it is in a high proportion common siderite laminae result which is characteristic for composite couplets. As a consequence, the lake marginal setting contains substantially higher (by an order of magnitude) amounts of siderite than the basinal lake area. It forms poorly crystallised very fine ribbons $(20 \times 5 \mu \mathrm{m}$ on average $)$ randomly dispersed in a clayey-silt matrix (Fig. 8). In several sandy lay- ers it is associated with traces of calcite, which tends to form coarse poikilotopic grains. From chemical analysis, the mean composition of finely dispersed siderite ribbons and laminae is $\mathrm{Fe}_{0.67} \mathrm{Ca}_{0.10} \mathrm{Mg}_{0.22} \mathrm{Mn}_{0.02} \mathrm{CO}_{3}$ (Lojka et al. 2009).

\section{$\delta^{18} \mathrm{O}$ and $\delta^{13} \mathrm{C}$ composition of siderite}

The lake marginal area contains a large number of siderite laminae as it is dominated by composite couplet lamination, and also massive or several centimetre thick laminated horizons. Such horizons also occur in the basinal lacustrine setting, but discrete thin siderite laminae are less common, instead, detrital half-couplets are locally impregnated by dispersed siderite crystallites. Siderite horizons are almost free of detrital grains and often contain zooclasts, coprolites and dispersed organic matter. The millimetre-scale lamination consists of alternating fine and 

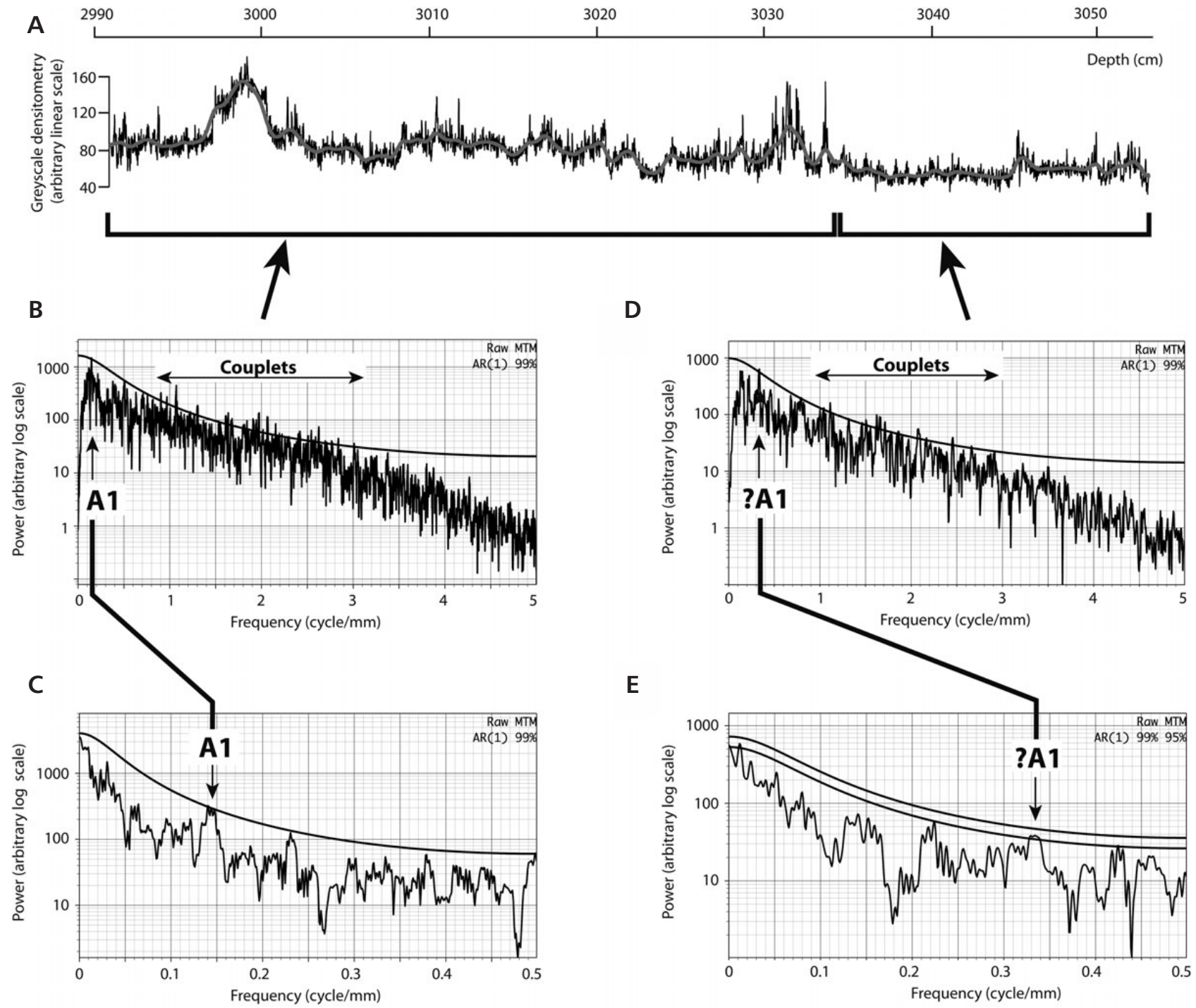

Figure 9. A - greyscale-densitometry series from a relatively homogeneous portion of claystone with irregular lamination type I. The grey curve indicates a low-frequency component (Gaussian filter, $0.02 \pm 0.08 \mathrm{cycle} / \mathrm{mm}$ ) which accommodates approximately $80 \%$ of the total variance. $\bullet B-$ spectral estimate for the upper part of the greyscale series. The series was resampled at $0.1 \mathrm{~mm}$, and the lowest-frequency component $(0.02 \mathrm{cy}-$ $\mathrm{cle} / \mathrm{mm}$ ) was removed using a Gaussian filter (bandwidth 0.08 ) in order to isolate a relatively high-frequency signal. The couplet signature and the A1 signal are indicated. $\bullet \mathrm{C}$ - spectral estimates for the upper part of the greyscale series after resampling at $1 \mathrm{~mm}$ in order to highlight relatively low-frequency components. No filter applied. $\bullet \mathrm{D}$ - spectral estimate for the lower part of the greyscale series. The series was resampled at $0.1 \mathrm{~mm}$, and the lowest-frequency component $(0.04 \mathrm{cycle} / \mathrm{mm}$ ) was removed using a Gaussian filter (bandwidth 0.08$)$. The couplet signature and a possible downward equivalent of the A1 signal are indicated. $\bullet \mathrm{E}$ - spectral estimate for the lower part of the greyscale series after resampling at $1 \mathrm{~mm}$. No filter applied.

coarse siderite crystallites, in which the finely crystallized laminae consist of $\mathrm{Mn}$ rich siderite, while the coarser laminae consist of siderite containing more $\mathrm{Mg}$ and quartz grain admixture (Fig. 8C). The $\delta^{13} \mathrm{C}$ component of siderite laminae in horizons varies significantly, with a range of $\sim 10 \%$ o (from $-12.07 \%$ in $\mathrm{Mg}$-rich siderite to $-0.08 \%$ in Mn-siderite) while the $\delta^{18} \mathrm{O}$ content is almost constant $(\sim 7.25 \%$ o). These compositional and related $\delta^{13} \mathrm{C}$ isotopic variations probably reflect various patterns of siderite formation in massive horizons, mainly affecting the dissolved carbon dioxide budget.
The $\delta^{18} \mathrm{O}$ and $\delta^{13} \mathrm{C}$ values of siderite from the lake margin vary systematically in a somewhat wider range (from -9.67 to $-2.25 \% \circ \delta^{18} \mathrm{O}$, and from -11.75 to $7.07 \% \circ \delta^{13} \mathrm{C}$ ) than in the basinal lake area (from -7.53 to $-3.83 \% \circ \delta^{18} \mathrm{O}$, and from -11.07 to $1.63 \% \circ \delta^{13} \mathrm{C}$, Fig. 14). A different range of isotopic values probably reflects different distances to the inflows that mainly control local hydrology. The $\delta^{18} \mathrm{O}$ and $\delta^{13} \mathrm{C}$ values of siderite from the lake marginal area delineate cyclic oscillations, especially in the series with composite couplets and couplet lamination (Fig. 14). 

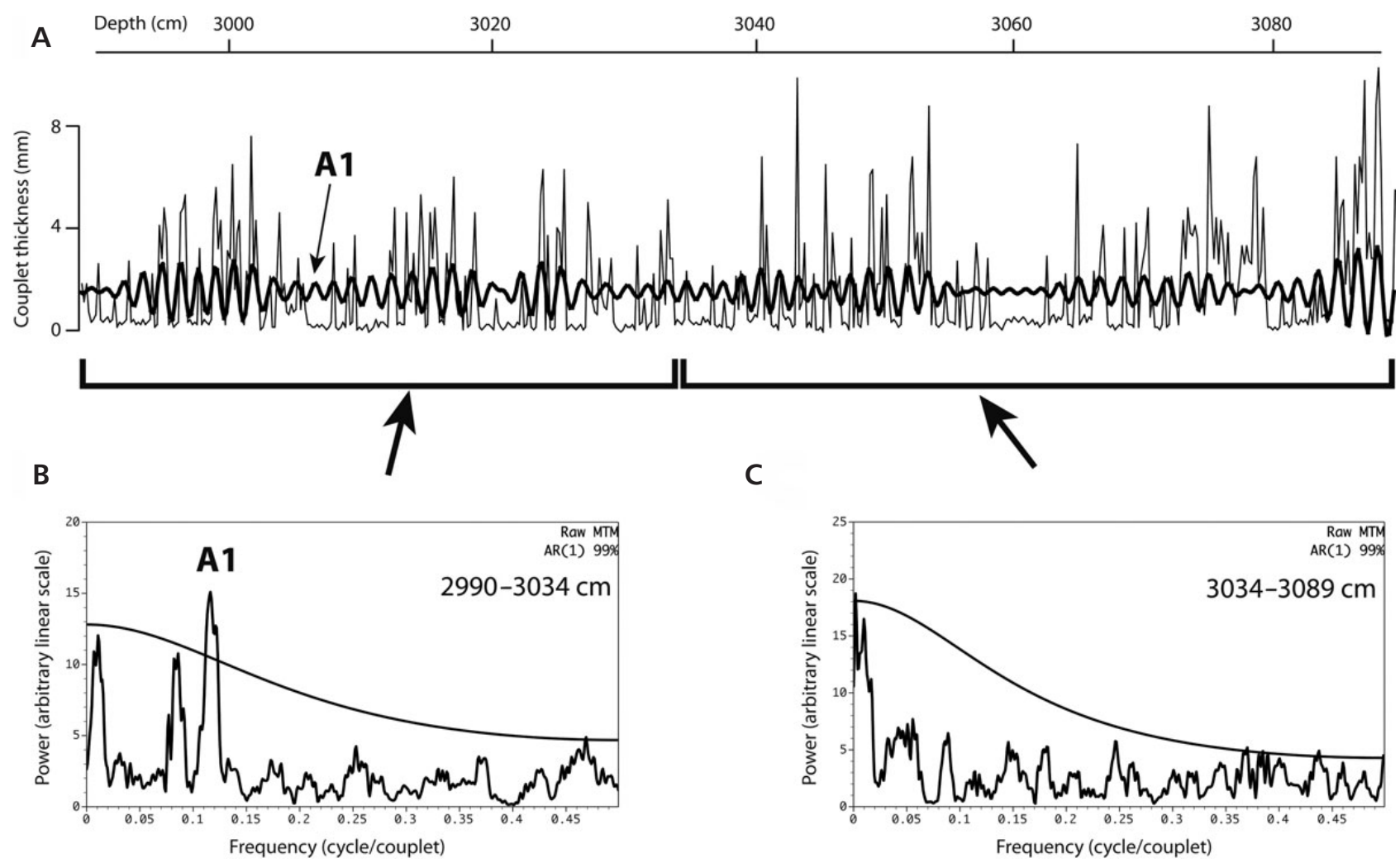

Figure 10. A - couplet-thickness series from part of the claystones with irregular lamination type I. This interval mostly overlaps with the interval shown in Fig. 9. The thick, black curve indicates the contribution of the A1 signal. $\bullet$ B - spectral estimate for the upper portion of the couplet-thickness series. The A1 signal is indicated. $\bullet \mathrm{C}$ - spectral estimates for the lower part of the couplet-thickness series. Note that the A1 signal is not visible in the spectral estimate. However, a greater variance is located in low frequencies. See text for discussion.

Although there is no clear and simple relationship between isotopic values and lamination patterns, it can be stated that lower isotopic values tend to occur in welldeveloped composite couplets or in generally carbonate-free claystones with irregular lamination. In contrast, the higher values tend to occur in intervals with couplet lamination or thinly developed composite couplets (up to $2 \mathrm{~cm}$ ) and in carbonate-rich irregularly laminated claystones at the top of the offshore-lacustrine facies association. A quite discontinuous isotopic record from the basinal lake area revealed less clear cyclic oscillations which are imposed on a long-term trend of increasing $\delta^{18} \mathrm{O}$ values culminating in a pronounced $4 \mathrm{~m}$ thick siderite-rich interval with a gradual increase up to the highest isotopic values. This interval, underlying the prodeltalacustrine facies association, corresponds well to similarly thick carbonate and bituminite rich clayey-silt interval in the marginal lake area.

Strictly parallel oscillations of both the $\delta^{13} \mathrm{C}$ and $\delta^{18} \mathrm{O}$ values were observed in the marginal lake $(\mathrm{r}=0.89)$, while the weak covariance $(\mathrm{r}=0.54)$ was observed in the basinal lake area. Vertical trends in distribution and mineralogy of carbonates and isotopic composition of siderite were quite similar in both cores (Figs 3, 4).

\section{Lamination cyclicity}

Frequency analysis of lamination is illustrated for irregular lamination Type I and couplet lamination subtype IIa from the basinal lacustrine setting (Tr-1). Two aspects were examined: greyscale variations reflecting lithology (Figs 9, 11) and the couplet thicknesses which record sedimentation rates or magnitudes of sedimentation change (Figs 10, 12). A possible "real", statistically significant cyclicity of lamination was expected to affect both the greyscale variations and couplet thicknesses in each type of lamination. Different significant frequencies were expected in the two types of lamination because of their different disposition towards recording seasonal contrasts. A more regular, possibly seasonal record was expected in couplet lamination subtype IIa, which should hence produce a certain frequency pattern corresponding to the actual previous climate forcing. An irregular, poor seasonal record was expected in the lamination Type I representing condensed sedimentation. Frequency analysis was performed to reliably evaluate these ideas.

All greyscale series (Figs 10, 12) are rather noisy and do not exhibit distinct spectral maxima attributable to 
couplet-scale cyclicity. Broad intervals of significant (>99\%) frequencies occur at $0.5-3.1$ cycle/mm $(0.30-2.0 \mathrm{~mm}$ period, Type I lamination, Fig. 10), and $0.35-2.5 \mathrm{cycle} / \mathrm{mm}$ (0.4-2.8 mm period, subtype IIa lamination, Fig. 12). By definition, the couplet-thickness series cannot reveal cyclicity on the scale of the individual couplets.

\section{Cyclicity in lamination Type I \\ (Tr-1, interval: 31.1-29.9 m)}

In greyscale series, a significant frequency was found at $0.14 \mathrm{cycle} / \mathrm{mm}(\sim 7 \mathrm{~mm}$ period $)$ in the upper part of the interval examined (cycle A1; Fig. 9). The middle part of the interval, which is notably less silty (darker in colour) compared to the upper part, shows a significant peak at 0.33 cycle $/ \mathrm{mm}$ ( $3 \mathrm{~mm}$ period). Other frequency maxima appear statistically insignificant $(<99 \%$ confidence level). The couplet-thickness series (Fig. 10) reveals one significant frequency centred at 0.115 cycle/couplet (i.e., 1 : 9 couplet bundling) in the upper subinterval examined. This signal is equivalent to the A 1 cycle in the greyscale series and corresponds to a systematic switching between sets of homogeneous couplets (typically 4-6) and sets of silty clusters (typically 3-5). This distinct pattern becomes less apparent downward with an increase in the proportion of homogeneous couplets vs. silty clusters.

\section{Cyclicity in lamination subtype lla (Tr-1, interval: 26.7-25.3 m)}

Two distinct spectral maxima were found in the greyscale-densitometry series from the lower part of the interval examined: $0.015 \mathrm{cycle} / \mathrm{mm}(67 \mathrm{~mm}$ period; B1 in Fig. 11) and 0.12 cycle/mm (8 mm period; B2 in Fig. 11). Similar, although statistically less significant frequencies occur in the upper portion of the study interval. The greyscale-densitometry signals B1 and B2 have possible counterparts in the couplet-thickness spectra: 0.009-0.018 cycle/couplet (B1 in Fig. 12) and 0.13-0.17 cycle/couplet (B2 in Fig. 12) in the lower and middle subintervals. They suggest 1 to (6-8) to (55-111) couplet bundling. More importantly, the amplitude envelope of the B2 cycle is strongly coherent $(>95 \%)$ with the B1 cycle suggesting either a causal relationship between the two cycles that they were driven by or a common force.

Filtering of the individual components suggests that noise levels increase towards the top, thus masking the B2 signature. Elevated noise levels due to increased winnowing and/or siliciclastic input could also be responsible for deterioration of the coherence between the B1 cycle and B2 amplitude modulation in the upper part of the interval. The upward loss of these clear statistical relationships towards the interval of increasing amalgamation of couplets could be a consequence of the distortion of the regular "seasonal" record due to an absence of (some) organic-clay half-couplets representing "calm" seasons.

\section{Discussion}

\section{Palaeoenvironment and hydrology of the Mšec Lake}

Prevailing fine siliciclastic sedimentation accompanied by persistent organic matter production and preservation, and absence of evaporative facies or exposure surfaces indicate sedimentation in a deep, at least temporally stratified freshwater reservoir. Initially the balanced-fill lake basin gradually evolved to become an overfilled lake sensu Carroll \& Bohacs (1999), as continuously increasing sediment supply exceeded potential accomodation. Dominance of siderite as the main lacustrine mineral in the offshorelacustrine facies association is indicative of persistent low sulphate waters and an organic-rich environment. Distinct siderite particle morphology, idiomorphic crystal shape and homogeneous grain-size distribution supports biologically induced and/or mediated precipitation from the lake water at lower parts of the hypolimnion or in the shallow sub-surface zone under conditions not significantly different from those of the hypolimnion (Talbot \& Kelts 1990). Equivocal covariance of carbonate isotopic compositions (Fig. 15) as well as varying ranges of both carbonate isotopic signatures (Fig. 14) suggest different conditions of siderite precipitation when comparing the two lake areas. A narrow range of negative isotopic values and common presence of bituminite and pyrite in the basinal lake may reflect longer residence times of the permanently thermally stratified hypolimnion, inhibiting lake water mixing. Wide range and covariant fluctiations of siderite isotopic values from the lake marginal area indicate relatively closed hydrological conditions which were more sensitive to significant changes in the water column and/or surrounding environment.

The $\delta^{13} \mathrm{C}$ composition of siderites mainly depends on their dissolved carbonate source (originating from both organic matter decay and atmospheric $\mathrm{CO}_{2}$ ) and it is hence more variable and facies- or site-specific than the $\delta^{18} \mathrm{O}$, which reflects the composition and temperature of sediment pore waters at the time of precipitation (Leng \& Marshall 2004). In the low-sulphate waters, the bacterial sulphate reduction is almost insignificant and completed within the uppermost centimetre of the sediment surface (Lovley \& Klug 1986). This allows the bacterial methanogenic processes to dominate the earliest stages of diagenesis in lake sediments (Talbot \& Kelts 1990) leading to very positive $\delta^{13} \mathrm{C}$ values, which was probably the case for several intervals in the marginal lake setting (up to $\sim 7 \%$ o $\left.\delta^{13} \mathrm{C}\right)$. The quasi-periodic fluctuations in the oxygen and 


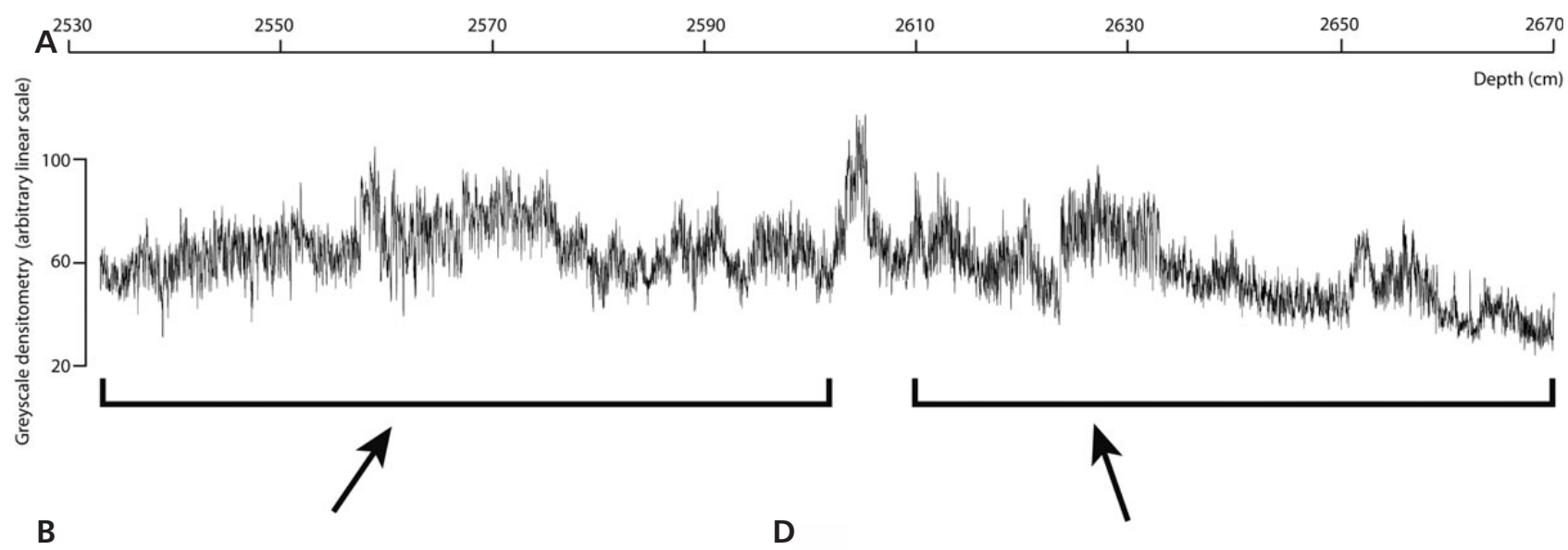

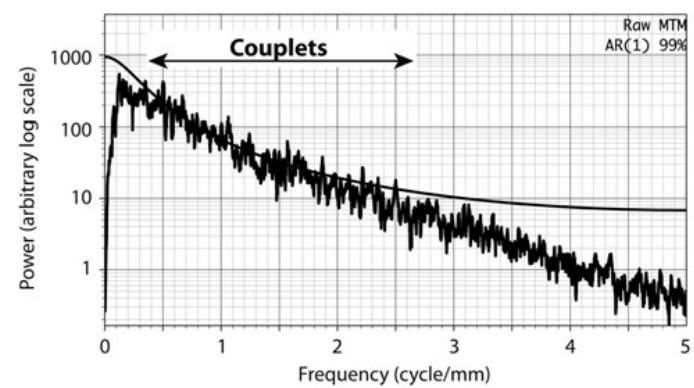

C ?B1

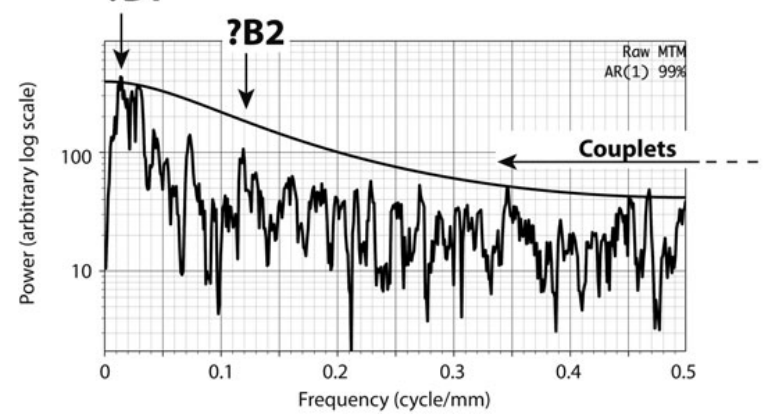

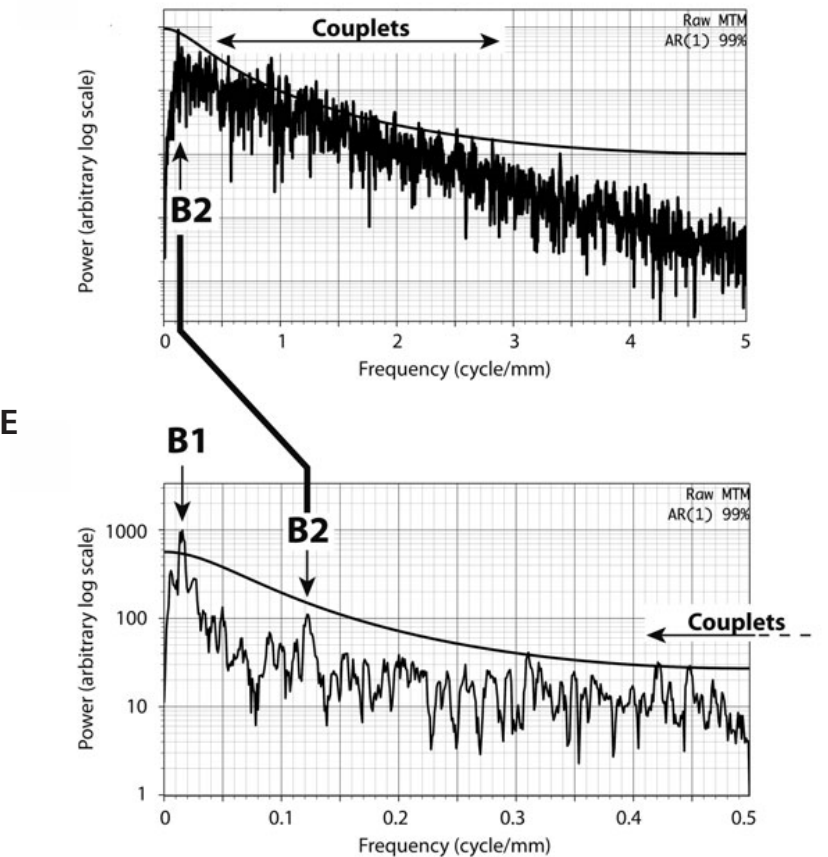

Figure 11. A - greyscale-densitometry series from a relatively homogeneous portion of couplet lamination type IIa. $\bullet \mathrm{B}-\mathrm{spectral}$ estimate for the upper part of the greyscale series. The series was resampled at $0.1 \mathrm{~mm}$, and the lowest-frequency component $(0.02 \mathrm{cycle} / \mathrm{mm})$ was removed using a Gaussian filter (bandwidth 0.08) in order to isolate a relatively high-frequency signal. The couplet signature is indicated. $\bullet \mathrm{C}-$ spectral estimates for the upper part of the greyscale series after resampling at $1 \mathrm{~mm}$ in order to highlight relatively low-frequency components. No filter applied. Possible equivalents of the B1 and B2 signals are indicated. $\bullet$ D - spectral estimate for the lower part of the greyscale series. The series was resampled at $0.1 \mathrm{~mm}$, and the lowest-frequency component $(0.01$ cycle $/ \mathrm{mm})$ was removed using a Gaussian filter (bandwidth 0.08$)$. The couplet signature and the B2 signal are indicated. - E - spectral estimate for the lower part of the greyscale series after resampling at $1 \mathrm{~mm}$. No filter applied. B1 and B2 signals are indicated.

carbon isotope compositions of siderite from the lake's marginal area into $\sim 4 \mathrm{~m}$ thick cycles with rapid and prominent shifts in both $\delta^{18} \mathrm{O}$ and $\delta^{13} \mathrm{C}$ values, reaching $\sim 3 \%$ and $\sim 10 \%$, respectively (Fig. 14), may indicate periodic recurrence of eutrophic conditions marked by increased bacterial methanogenesis, low freshwater inflow and significant evaporation. Alternating intervals of low $\delta^{18} \mathrm{O}$ and $\delta^{13} \mathrm{C}$ values may reflect conditions of increased freshwater inflow, sediment supply and organic productivity. It is generally accepted that such substantial covariant fluctuations in the carbonate carbon and oxygen isotopic compositions reflect major variations in the lake water balance and the dissolved inorganic carbon budget (e.g., Leng \& Marshall 2004).

In addition to the diverse range of $\delta^{18} \mathrm{O}$ and $\delta^{13} \mathrm{C}$ values of authigenic siderite, the marginal and basinal lake areas also differ significantly in the distribution and maturity of liptinite macerals, the lacustrine algal material, especially in alginite/bituminite proportions and bituminite maturity, suggesting quite different conditions of organic matter decay. Bituminite is formed by bacterial degradation of primary biomass such as algae, bacterial lipids, degraded animal plankton and other precursors (Teichmüller 1974, 
A

$\begin{array}{llllll}\text { Depth }(\mathrm{cm}) & 2560 & 2580 & 2600 & 2620 & 2640\end{array}$
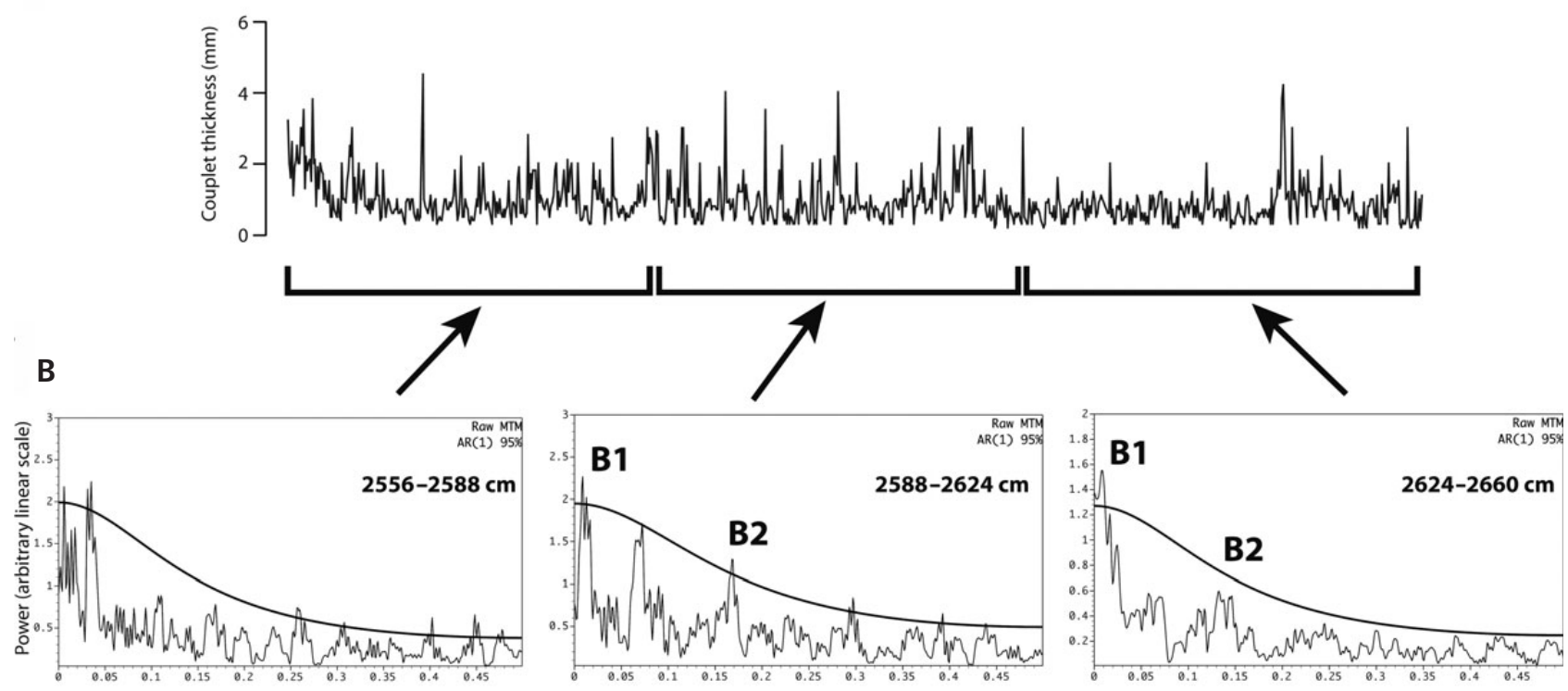

Frequency (cycle/couplet)

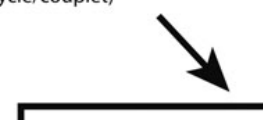

Frequency (cycle/couplet)

Frequency (cycle/couplet)
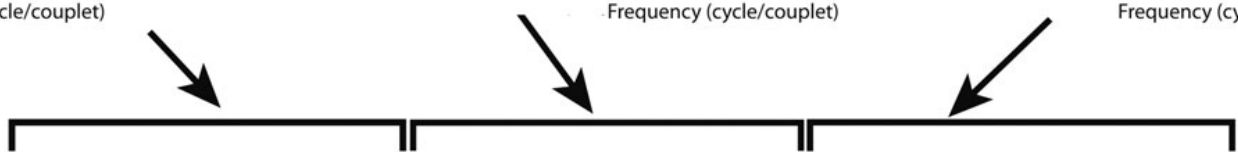

C

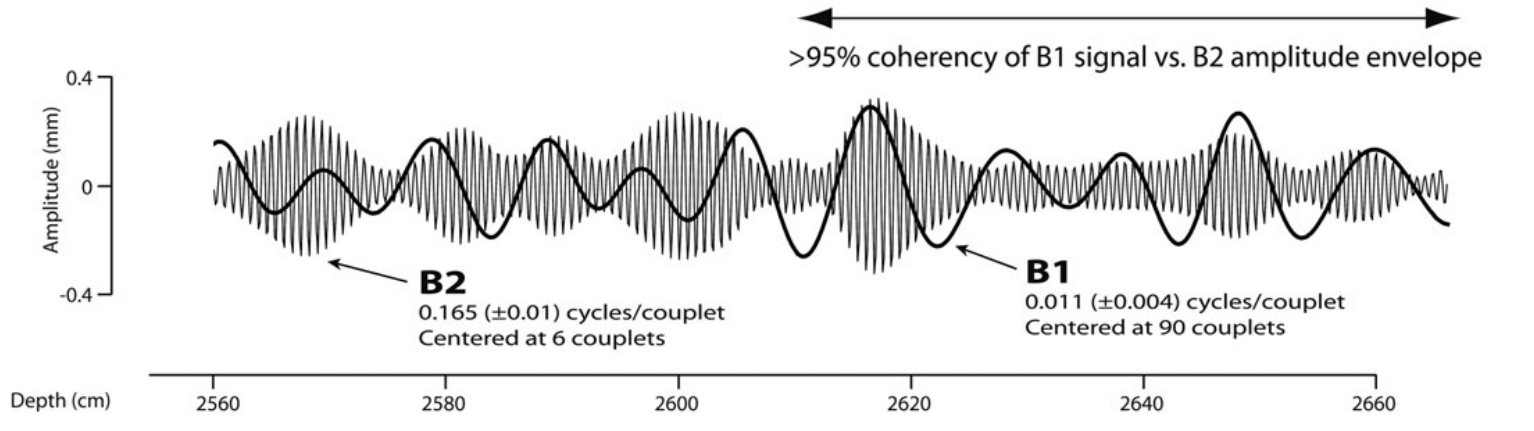

Figure 12. A - couplet-thickness series from part of the lamination type IIa. This interval mostly overlaps with the interval shown in Fig. 11 . B - spectral estimates for the upper, middle and lower portions of the couplet-thickness series. Signals B1 and B2 are indicated in the middle and lower parts of this interval. The confidence of B1 and B2 does not exceed 99\%. However, the amplitude envelope of B2 is strongly coherent with B1 between $c a 2610$ and $2660 \mathrm{~cm}$. $\cdot \mathrm{C}$ - suggesting that B1 and B2 are signals rather than random signatures.

Robl et al. 1992, Obermajer et al. 1997, Taylor et al. 1998, Rimmer et al. 2004). A high proportion of mature bituminite and very fine framboidal pyrite replacing organic particles in the basal claystones indicate prevailing reducing conditions which produce sulphidic minerals rather than siderite, which is precipitated only rarely, probably during more oxic events. In contrast, the lake marginal setting had lower and relatively well-balanced sulphur proportions, which are slightly increased in the bituminite-rich clayey siltstone interval at the top of the offshore-lacustrine facies association. The sharp increase in bituminite is probably at a time equivalent to the lamalginite peak in the basinal lake area suggesting basin-wide increased productivity, but variation in the organic matter decay processes. This indication of an at least partial fragmentation of the lacustrine system in the upper part of the offshorelacustrine facies association is further supported by the highest $\delta^{18} \mathrm{O}$ and $\delta^{13} \mathrm{C}$ values of siderite suggesting pronounced evaporation and widespread eutrophisation.

Distribution of terrestrial organic debris, represented by intertinite and the vitrinite group of macerals, is related to lamination patterns, as both are function of sediment supply. The onset of terrestrial organic-bearing couplet lamination on basal liptinite-rich claystones is also linked with a prominent change in lamalginite vs. bituminite proportions in the basinal lake area. While the lamalginite proportion remains high, the bituminite proportion sharply decreases with change in lamination. This shift in the lamalginite/bituminite ratio may reflect conversion from a relatively permanently stratified lake water column 


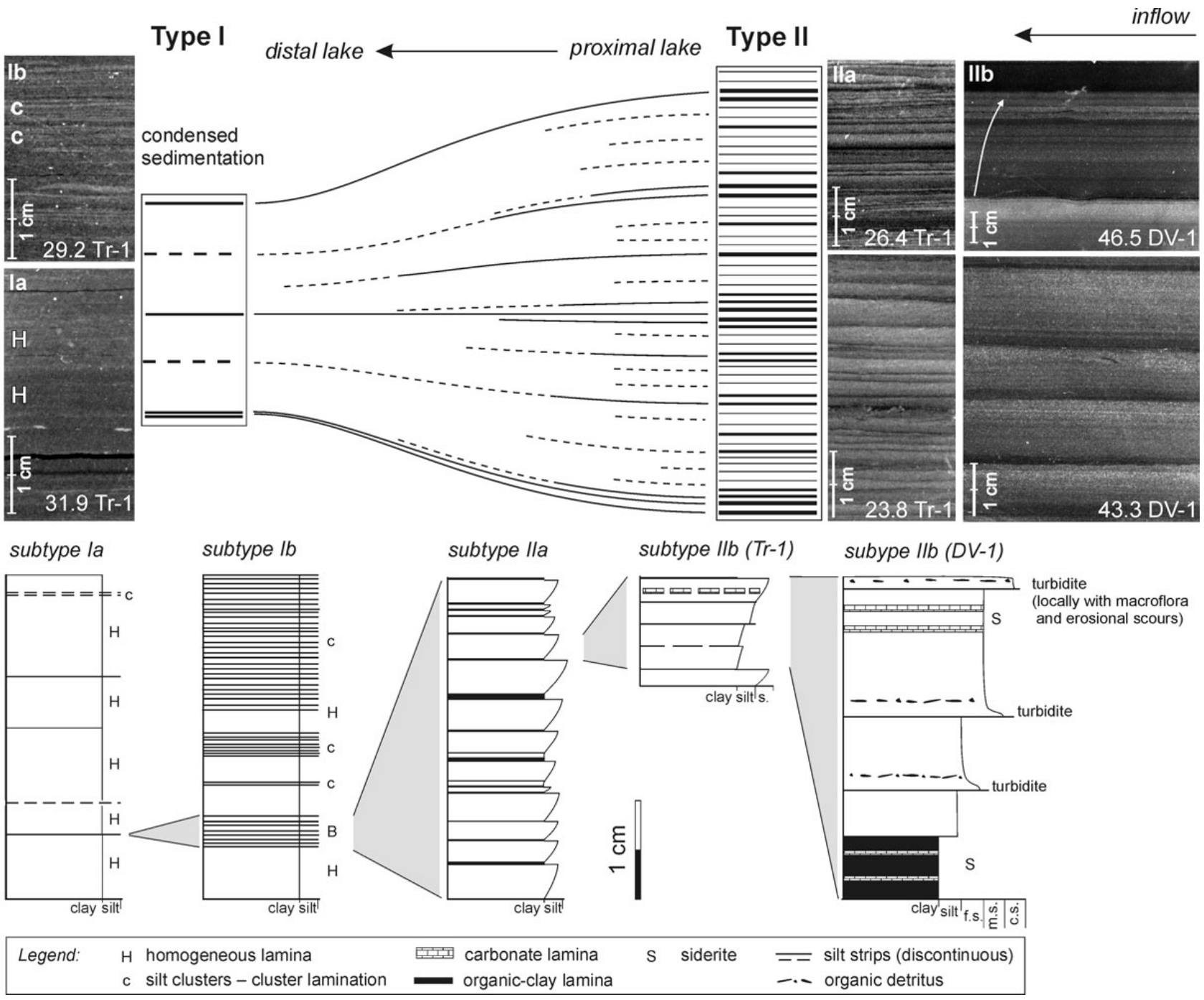

Figure 13. Possible relationship between the types of lamination mainly reflecting variation in sediment supply.

enabling organic matter preservation and storage, to an only partially, possibly seasonally, stratified situation, with advanced organic matter oxidation. Establishment of stable thermal stratification during the initial lake stage probably required a quite substantial water column and/or weak seasonal perturbations. Development of an at least partial seasonal overturn probably inhibited the bacterial degradation of algal material in favour of its more advance oxidation. This change in lake hydrology proceeded without significant changes in primary productivity as indicated by the steady proportion of lamalginite. The original total volume of organic matter in the lake could had been even higher due to an increased supply of terrestrial organic debris linked with the onset of couplet lamination in the basinal lake area or equivalent onset of composite couplet lamination in the marginal lake area. Both relative maxima of inertinite macerals from the marginal lake correspond to isotopically dense intervals comprising irregular and cou- plet laminations (Fig. 4). High reflectance values of fusinite particles $\left(1.1 \%-2.9 \% \mathrm{R}_{\mathrm{I}}\right)$ indicate their formation under high temperatures (Scott \& Jones 1994), most probably generated by wildfires in the lake drainage basin. Such material is easy to transport, some inetodetrinite particles may had been aeolian-transported as was observed by Rimmer et al. (2004).

\section{Seasonal origin of couplet-lamination}

Lowland tropical regions are usually not affected by such dramatic seasonal or multiannual variations in temperature and insolation as high latitude and/or high altitude areas where varve-like lacustrine sediments are quite common. The sediments in modern tropical lakes are not always regularly laminated (Pilskaln \& Johnson 1991, Crausbay et al. 2006), and where they are, the assignment of lamination 

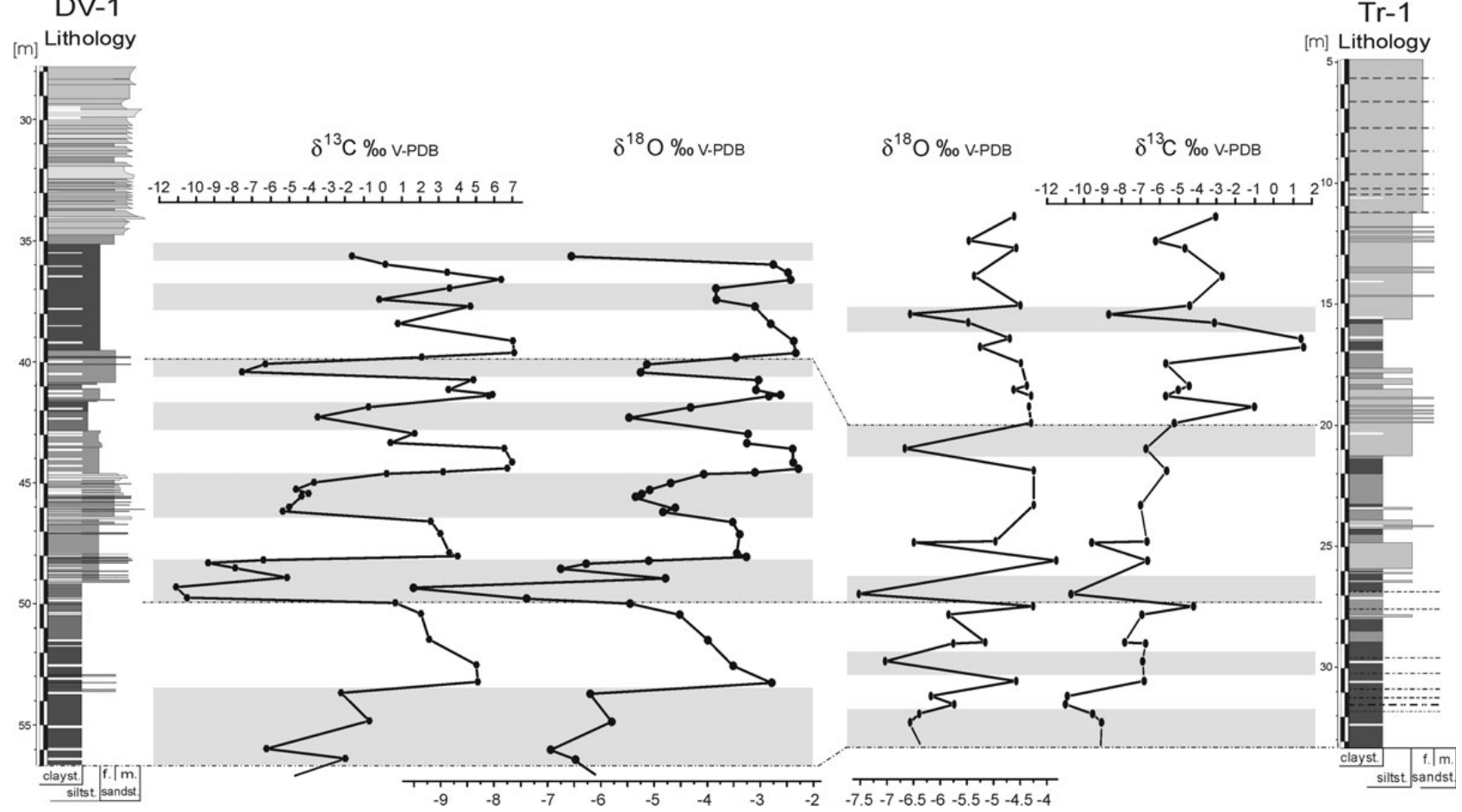

Figure 14. Proposed correlation of cores based on isotopic composition of siderite, distribution of lamination patterns and dispersed organic macerals. Both cores are expressed in the same scale to more clearly evaluate different ranges and shifts of isotopic values. Note prominent basin-wide low stand marked by steady high isotopic values.

as true seasonal couplets needs particular attention and is hardly unequivocal without the presence of accurate time constraints. The commonest reason for seasonal lamination in modern tropical lakes is the regular variation in precipitation controlled by monsoonal circulation. Offshore deposits at Lake Tanganyika (Cohen et al. 2006) and other African Rift lakes (Pilskaln \& Johnson 1991, Halfman \& Johnson 1988), and additional tropical lakes (Crausbay et al. 2006) show lamination controlled by the seasonally driven fluvial input of siliciclastics "diluting" biogenic sediment components, in the recent time mostly diatom frustules.

A similar lamination pattern is observed in the Stephanian B Mšec/Malesice Member, where the alternating autochthonous biogenic-lacustrine and allochthonous detrital laminae form couplet lamination in a thick and continuous series which reflect the persisting high-frequency periodic changes in sediment supply diluting algal production. Upward coarsening of grain-size in couplets, results most probably from steady to fluctuating hyperpycnical density-driven underflows, which are the most important agents for transporting silt-grade sediment into deep-water lacustrine settings (Collinson et al. 2006). These flows typically occur in tropical lakes where cold river water, usually also rich in suspended material, enters the warmer lake. Such flows can be seasonally persistent and tend to vary between accumulating and erosive. Reverse grading in couplets may indicate the continuously increasing capacity of such flows, reflecting gradually increasing sediment supply during each season. Several discrete pulses of sediment supply were recognized within detrital half-couplets in composite couplet lamination (subtype IIb), the proximal equivalent of couplet lamination (Fig. 13). Some of these pulses represent single-event turbidity flows as indicated by the erosional bases and well-developed gradations in the fine sandy material (Collinson et al. 2006). Coarse-grained couplet tops are usually sharp, matching an abrupt decrease in clastic sediment supply.

According to these observations, it is clear that the couplet structure records regular alternation of two distinct seasons with markedly different conditions. The organic half-couplets correspond to rather dry seasons accompanied by algal blooms and low sediment supply and possibly increased aeolian activity. In contrast, the detrital half-couplets reflect humid seasons with increased terrestrial productivity and fluvial activity bearing more clastic material to the lake. The transition from dry to wet season was almost continuous, in contrast to the rather abrupt onset of the dry season. The onset of humid seasons was probably characterized by gradually increasing intensity of precipitation as indicated by the reverse grading. Due to the absence of precise timing constraints it is, however, difficult to assign the described seasonal alteration to semi-annual, annual or multi-annual seasonality. Such assignment 

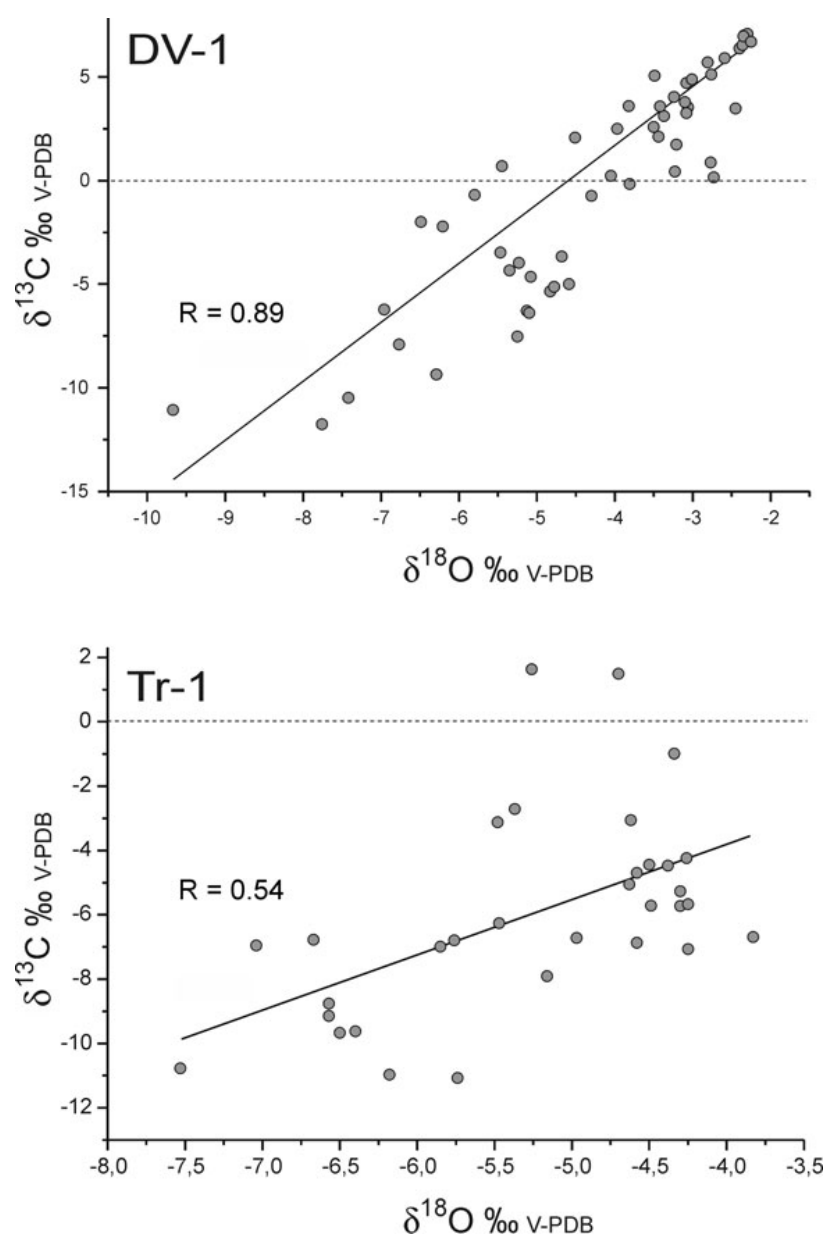

Figure 15. Correlation of isotopic values from both lake areas indicates slightly different conditions of siderite precipitation.

strongly depends on the sensitivity of the lacustrine sedimentary system and its ability to record seasonal changes. This sensitivity varied throughout the life-time of the lake, with changing conditions in the lake (e.g. extent, depth) and its surroundings (e.g. drainage to lake area ratio). Additional effects such as atmospheric-pressure changes similar to the present-day Quasi-Biennial Oscillation (Baldwin et al. 2001) might have modified the local seasonal pattern, possibly producing biennial sedimentary couplets, where each couplet would represent two years with only one extreme season preserved. Although the strong inequality of detrital half-couplets in parts of the laminated intervals (Fig. 6C) could be consistent with biennial oscillations, the available data do not constitute evidence for such a scenario. However, the series of couplet lamination shows statistically significant variations in the thickness rhythm, reflecting varying sedimentation rates and accompanying changes in the ratio of organic vs. detrital half-couplets, indicating lower frequency changes in clastic sediment supply. Time-series analysis of the laminae thickness could at least indirectly support the assignment of the couplet lami- nation (subtype IIa) to seasonal cycles, as statistically significant frequencies are expected in the seasonal record under a monsoonal climate, similarly to that in modern tropical lake sediments (Halfman \& Johnson 1988, Cohen et al. 2006, Stager et al. 2007).

\section{Lamination cyclicity}

Spectral maxima A1 (Type I lamination), B1 and B2 (subtype IIa lamination) are interpreted to reflect systematic, repeated changes in couplet thickness. In both intervals these changes are primarily due to variations in silt contents, which are interpreted here as due to changes in precipitation. The A1 signal from irregular lamination (Type I) is controlled by the distribution of homogeneous laminae and corresponds to systematic switching between sets of homogeneous couplets (typically 4-6) and sets of silty clusters (typically 3-5 thin couplets). Considering that each homogeneous couplet is most probably a distal expression of a set of regular couplets (Type II lamination, Figs 6 and 13), the $1: 9$ bundling revealed by the A1 signal must be a relic feature reflecting a higher-order cyclicity. The homogeneous couplets are typically thicker, by an order of magnitude, than the adjacent very thin silt couplets suggesting that approximately 10 silty couplets might have been amalgamated into one homogeneous lamina. Therefore the A1 bundling could reflect a longer term, multidecadal (perhaps 50- to 70-couplet) signal. The downward disappearance of the A1 signal in the couplet-thickness series is accompanied by a shift of the prominent frequency from 0.14 cycle/mm to 0.33 cycle $/ \mathrm{mm}$, i.e., a decrease in the signal period, in the greyscale series. These patterns are consistent with lower sedimentation rate and increasing condensation of silt couplets towards the base of the offshore-lacustrine facies association. The upward thickening of couplets and similarities between A1 ( $c$ a 50- to 70-couplet) and B1 (55- to 111-couplet) periodicities suggest that this trend continues in the opposite direction, i.e., towards the couplet lamination subtype IIa (shift from $c a$ $0.14 \mathrm{cycle} / \mathrm{mm}$ to $\mathrm{ca} 0.015 \mathrm{cycle} / \mathrm{mm}$ ). Cycle B 1 is a likely follow-up of the A1 signal, which is a relic feature due to condensed sedimentation. Similarly, based on thickness ratios of silty vs. homogeneous couplets (see above) it appears possible that the B2 signal ( $\mathrm{ca} 1: 6-8$ ) is an upward equivalent of homogeneous couplets. It is possible that the same driving mechanisms controlled the periodic signals of silt distribution in both lamination records. Importantly, the coherence of B2 amplitude modulation and B1 signal suggests that the B1 and B2 bundles in the couplet lamination subtype IIa were linked to the same mechanism.

The only periodic or quasi-periodic driving mechanism known to operate on annual to decadal scales is a set of solar (sunspot) cycles, which include ca 11-yr (Schwabe), 
22-yr (Hale) and 60-120-yr (Wolf-Gleissberg) quasi-periods (e.g., review in Usoskin 2008). Although the observed bundling, namely the $\mathrm{B} 2$ component, is dissimilar to the theoretical periods, the periodic, multi-decadal amplitude modulation of the B2 signal is a pattern similar to that observed in recent sunspot records (World Data Center for the Sunspot Index, Royal Observatory of Belgium). Clearly, the basic Schwabe cycle cannot be present in any climatic record without the Gleissberg cycle, which defines the amplitude of 11-yr sunspot variation. This key feature is reproduced in the couplet lamination subtype IIa. Dissimilarities of the observed periodic bundling and recent theoretical periods do not allow the assignment of described couplets to annual-seasonal cycles without precise time constraints. However, the statistically significant higher-order periodicity in silt supply revealed an external control on seasonal variations (i.e., couplet thickness and organic/detrital half-couplet proportions).

The onset of seasonality in equatorial tropics at the Permo-Pennsylvanian boundary is attributed to the onset of the global Pangaean monsoon, enhanced by the Pangaea "supercontinentality" (Soreghan \& Soreghan 2007, Tabor \& Poulsen 2008). The global "mega-monsoonal" circulation perceptible in Pangaean tropics was undoubtedly established during the Permian, but there is evidence of monsoonal climates already in the Pennsylvanian (Soreghan \& Soreghan 2007) or even Mississippian (Falcon-Lang 1999). The Stephanian B Mšec Member lacustrine series record the onset of seasonality in precipitation in the central-east Pangaean tropics during a relatively humid climate phase in this region (Opluštil \& Cleal 2007). The observed seasonal distribution of precipitation is consistent with extensive loessite deposits attributed to a monsoonal climate that developed in the similar stratigraphic interval in the western tropical Pangaea (Soreghan \& Soreghan 2007).

\section{Conclusions}

A $\sim 22$ m thick series of continuously thinly laminated claystones and clayey to sandy siltstones represents the unique palaeoclimatic archive recording changing Mšec Lake palaeohydrology during a part of the Stephanian B in the central-east Pangaean tropics.

The variable composition of dispersed organic macerals together with distribution of lamination types revealed two end-member hydrological states of the lake. Dysoxic conditions of a permanently well-stratified hypolimnion reflect the highest lake level and produced a series of claystones rich in mature bituminite and pyrite with poorly developed irregular lamination. A series of continuous couplet lamination rich in alginite and terrestrial plant debris, but free of bituminite reflects conditions of a partially, possibly seasonally stratified hypolimnion and advanced organic matter oxidation. Apart from these two hydrological states, the lake passed through several wet-dry cycles probably lasting thousands of seasons which significantly affected the carbon and oxygen isotopic composition of autochthonous siderite and contributed to the final lake fragmentation revealed from a correlation of the two cores.

At least one type of lamination of the Mšec Lake fine siliciclastics, the couplet lamination, is of seasonal origin. The coarsening-up couplets start as fine organic-clay half-couplets, rich in autochthonous biogenic lacustrine material formed during seasons of algal blooms and suppressed siliciclastic input (dry seasons). Gradual transitions to detrital silty half-couplets rich in dispersed siderite and terrestrial plant debris correspond to a stepwise onset of humid seasons. Spectral analysis of the couplet-thickness series and grey-scale densitometry data revealed quasi-periodic, decadal- to centennial-scale changes in silt distribution in both lamination types (I and IIa). In spite of some similarities with solar cycles, the interpreted quasi-periods do not match theoretical quasi-periods of modern solar cycles. Therefore, the assignment of alternating wet and dry seasons to annual cycles remains uncertain.

\section{Acknowledgments}

The drilling and majority of analyses were funded by the Grant Agency of ASCR (KJB307020601 and IAA300460804). Additional geochemical analyses (XRF, CEC) were funded by project AV0Z40320502 and performed by Jana Dörflová and Petr Vorm, and XRD data acquisition by Antonín Petřina (Analytical Laboratory of the Institute of Inorganic Chemistry ASCR, v.v.i., Rež, the Czech Republic). We cordially thank Jaromír Leichmann (Masaryk University, Brno, the Czech Republic) for CL imaging. The authors thank to Gail Ashley, Petr Čejchan and Karel Žák for their helpful reviews.

\section{References}

Baldwin, M.P., Gray, L.J., Dunkerton, T.J., Hamilton, K., Haynes, P.H., Randel, W.J., Holton, J.R., Alexander, M.J., Hirota, I., Horinouchi, T., Jones, D.B.A., Kinnersley, J.S., Marquardt, C., Sato, K. \& TAKahashi, M. 2001. The QuasiBiennial Oscillation. Reviews of Geophysics 39, 179-229. DOI 10.1029/1999RG000073

CARroll, A.R. \& Bohacs, K.M. 1999. Stratigraphic classification of ancient takes: Balancing tectonic and climatic controls. Geology 27, 99-102.

DOI 10.1130/0091-7613(1999)027<0099:SCOALB>2.3.CO;2

Cohen, A.S. 2003. Paleolimnology. The History and Evolution of Lake Systems. 500 pp. Oxford University Press.

Cohen, A.S., Lezzar, K.E., Cole, J., Dettman, D., Ellis, G.S., Gonneea, M.E., Plisnier, P.D., Langenberg, V., BlaAuw, M. \& ZiLIFI, D. 2006. Late Holocene linkages between decadecentury scale climate variability and productivity at Lake 
Tanganyika, Africa. Journal of Paleolimnology 36, 189-209. DOI 10.1007/s10933-006-9004-y

Collinson, J., Mountney, N. \& Thompson, D. 2006. Sedimentary Structures. 292 pp. $3^{\text {rd }}$ edition, Terra Publishing, England.

Crausbay, S.D., Russell, J.M. \& SchnurRenberger, D.W. 2006. A ca. 800-year lithologic record of drought from sub-annually laminated lake sediment, East Java. Journal of Paleolimnology 35, 641-659. DOI 10.1007/s10933-005-4440-7

Crowell, J.C. 1999. Pre-Mesozoic Ice Ages: Their bearing on understanding the climate system. Geological Society of America Memoir 192, 1-106.

Crowley, T.J. \& BAum, S.K. 1991. Estimating Carboniferous sea-level fluctuations from Gondwana ice extent. Geology 19, 975-977.

DOI 10.1130/0091-7613(1991)019<0975:ECSLFF>2.3.CO;2

Crowley, T.J. \& Baum, S.K. 1992. Modeling late Paleozoic glaciation. Geology 20, 507-510. DOI 10.1130/0091-7613(1992)020<0507:MLPG>2.3.CO;2

FAlCON-LANG, H.J. 1999. The Early Carboniferous (Courceyan-Arundian) monsoonal climate of the British Isles: evidence from growth rings in fossil woods. Geological Magazine 136, 177-187. DOI 10.1017/S0016756899002307

Fielding, C.R., Frank, T.D., Birgenheier, L.P., Rygel, M.C., Jones, A.T. \& RoberTs, J. 2008. Stratigraphic record and facies associations of the late Paleozoic ice age in eastern Austgralia (New Asouth Wales and Queensland). Geological Society of America, Special Paper 441, 41-57.

FraKes, L.A. \& Francis, J.E. 1988. A guide to Phanerozoic cold polar climates from high-latitude ice-rafting in the Cretaceous. Nature 333, 547-549. DOI 10.1038/333547a0

GentZIS, T. \& Goodarzi, F. 1994. Reflectance suppression in some Cretaceous coals from Alberta, Canada, 93-110. In Mukhopadhyay, P.K. \& Dow, W.G. (eds) Vitrinite reflectance as a maturity parameter: applications and limitations. American Chemical Society Symposium Series 570.

GöTZE, J. 2000. Cathodoluminescence microscopy and spectroscopy in applied mineralogy. Technische Universität Bergakademie Freiberg, Germany.

GötZe, J. \& ZimmerLe, W. 2000. Quartz and silica as quide to provenance in sediments and sedimentary rocks. Contributions to Sedimentary Geology 21. E. Schweizerbart'sche Verlagsbuchhandlung, Stuttgart.

Gradstein, F.M., OgG, J.G., Smith, A.G., Agterberg, F.P., Bleeker, W., Cooper, R.A., Davydov, V., Gibbard, P., Hinnov, L.A., House, M.R., Lourens, L., LuterbaChER, H.P., McArthur, J., Melchin, M.J., RobB, L.J., Shergold, J., Villeneuve, M., Wardlaw, B.R., Ali, J., Brinkhuis, H., Hilgen, F.J., Hooker, J., Howarth, R.J., Knoll, A.H., Laskar, J., Monechi, S., Plumb, K.A., Powell, J., RafFi, I., Röhl, U., Sadler, P., Sanfilippo, A., Schmitz, B., Shackleton, N.J., Shields, G.A., Strauss, H., Van Dam, J., Van Kolfschoten, T., Veizer, J. \& Wilson, D. 2004. A Geologic Time Scale 2004. Cambridge University Press.

Halfman, J.D. \& Johnson, T.C. 1988. High-resolution record of cyclic climatic change during the past $4 \mathrm{ky}$ from Lake Turkana, Kenya. Geology 16, 496-500. DOI 10.1130/0091-7613(1988)016<0496:HRROCC >2.3.CO;2

Hasselmann, K. 1976. Stochastic climate models I: theory. Tellus 28(6), 473-485. DOI 10.1111/j.2153-3490.1976.tb00696.x
Havlena, V. 1961. Svrchnopaleozoické kontinentální uloženiny a jejich fytostratigrafie $\mathrm{v}$ měřitku geologických stupňủ a podstupňn. Časopis pro mineralogii a geologii 6, 82-91. [in Czech with English summary]

Havlena, V. \& PešEK, J. 1980. Stratigrafie, paleogeografie a základní strukturní členění limnického permokarbonu Čech a Moravy. Sborník Příroda 34. Plzeň. [in Czech]

Holub, V., SKočEk, V. \& TÁsLer, R. 1975. Paleogeography of Late Paleozoic in Bohemian Massif. Palaeogeography, Palaeoclimatology, Palaeoecology 18, 313-332.

DOI 10.1016/0031-0182(75)90039-5

Howell, P. 2001. ARAND time series and spectral analysis package for the Macintosh, Brown University. IGBP PAGES/World Data Center for Paleoclimatology Data Contribution Series 2001-044. NOAA/NGDC Paleoclimatology Program, Boulder, Colorado, USA.

Hutton, A.C. 1987a. Petrographic classification of oil shales. International Journal of Coal Geology 8, 203-231. DOI 10.1016/0166-5162(87)90032-2

Hutton, A.C. 1987b: Petrographic approach to beneficiation of Australan oil shales. Fuel 66, 314-318.

Hutton, A.C. \& Cook, A.C. 1980. Influence of alginite on the reflectance of vitrinite from Joadja, NSW, and some other coals and oil shales containing alginite. Fuel 59, 711-714.

ICCP 1998. The new vitrinite classification (ICCP System 1994). Fuel 77, 349-358.

ICCP 2001. The new inertinite classification (ICCP System 1994). Fuel 80, 459-471.

ISO 7404, 2009. Methods for the petrographic analysis of coal, http://www.iso.org/iso/catalogue_detail.htm?csnumber=42798.

Kalkreuth, W. \& Macauley, G. 1989. Organic petrology and Rock-Eval studies on oil shales from Lower Carboniferous Rocky Brook Formation, western Newfoundland. Bulletin of Canadian Petroleum Geology 37, 31-42.

LenG, M.J. \& Marshall, J.D. 2004. Palaeoclimate interpretation of stable isotope data from lake sediment archives. Quaternary Science Reviews 23, 811-831.

DOI 10.1016/j.quascirev.2003.06.012

Lojka, R., Drábková, J., Zajíc, J., SÝkorová, I., Francư, J., Bláhová, A. \& Grygar, T. 2009. Climate variability in the Stephanian B based on environmental record of the Mšec Lake deposits (Kladno-Rakovník Basin, Czech Republic). Palaeogeography, Palaeoclimatology, Palaeoecology 280, 78-93. DOI 10.1016/j.palaeo.2009.06.001

LOVLEY, D.R. \& KLUB, M.J. 1986. Model of the distribution of sulfate reduction and methanogenesis in freswater sediments. Geochimica et Cosmochimica Acta 50, 11-18. DOI 10.1016/0016-7037(86)90043-8

ManN, M.E. \& LeEs, J.M. 1996. Robust estimation of background noise and signal detection in climatic time series. Climate Change 33, 409-445. DOI 10.1007/BF00142586

McCREA, J.M. 1950. On the isotopic chemistry of carbonates and a paleotemperature scale. Journal of Chemical Physics 18, 849-857. DOI 10.1063/1.1747785

Obermajer, M., Foyer, M.G., Goodarzi, F. \& Snowdon, L.R. 1997. Organic petrology andorganic geochemistry of devonian black shales in southwestern Ontario, Canada. Organic Geochemistry 26, 229-246.

DOI 10.1016/S0146-6380(96)00157-X 
OвRHEL, J. 1958. Malesické lupky v kladensko-rakovnické pánvi. Věstník Ústředního ústavu geologického 33, 68-71. [in Czech]

Opluštil, S. \& Cleal, C.J. 2007. A comparative analysis of some late carboniferous basins of Variscan Europe. Geological Magazine 144, 417-448. DOI 10.1017/S0016756807003330

Paillard, D., Labeyrie, L. \& Yiou, P. 1996. Macintosh program performs time-series analysis: Eos (Transactions, American Geophysical Union) 77, 379. DOI 10.1029/96EO00259

PARRISH, J.T. 1998. Interpreting Pre-Quaternary Climate from the Geologic Record. 338 pp. New York, Columbia University Press.

Pilskaln, C.H. \& Johnson, T.C. 1991. Seasonal signals in Lake Malawi sediments. Limnology and Oceanography 36, 544-557. DOI 10.4319/lo.1991.36.3.0544

PEšEK, J. 1994. Carboniferous of central and western Bohemia (Czech Republic). 95 pp. Czech Geological Survey, Prague.

Pešek, J., Holub, V., Malý, L., Martínek, K., Prouza, V., SPUdil, J. \& TÁsler, R. 2001. Geologie a ložiska svrchnopaleozoických limnických pánví C̆R. 243 pp. Czech Geological Survey, Prague. [in Czech]

Ratanasthien, B., Kandharosa, W., Chompusri, S. \& ChartPRASERT, S. 1999. Liptinite in coal and oil rocks in northern Thailand. Journal of Asian Earth Sciences 17, 301-306. DOI 10.1016/S0743-9547(98)00067-1

Rimmer, S.M., Thompson, J.A., Goodnight, A.A. \& Robl, T.L. 2004. Multiple controls on the preservation of organic matter in Devonian-Mississipian marine black shales: geochemical and petrographic evidence. Palaeogeography, Palaeoclimatology, Palaeoecology 215, 125-154.

Robl, T.L., RiMmER, S.M. \& BARRON, L.S. 1992. Organic petrography of Mississipian and Devonian shales in east-central Kentucky. Fuel 71, 267-271.

Rosenbaum, J. \& Sheppard, S.M.F. 1986. An isotopic study of siderites, dolomites and ankerites at high-temperatures. Geochimica et Cosmochimica Acta 50, 1147-1150. DOI 10.1016/0016-7037(86)90396-0

Roscher, M. \& Schneider, J.W. 2006. Permo-Carboniferous climate: Early Pennsylvanian to Late Permian climate development of central Europe in a regional and global context, 95-136. In Lucas, S.G., CAssinis, G. \& Schneider, J.W. (eds) Non-Marine Permian Biostratigraphy and Biochronology. Geological Society Special Publication 265, London.

Roscher, M., Berner, U. \& SchneIder, J.W. 2008. A Tool for the Assessment of the Paleo-Distribution of Source and Reservoir Rocks. Oil Gas - European Magazine 34, 131-137.

ScotT, A.C. \& Jones, T.P. 1994. The nature and influence of fire in the Carboniferous ecosystems. Palaeogeography, Palaeoclimatology, Palaeoecology 106, 91-112.

DOI 10.1016/0031-0182(94)90005-1

ScheFfler, K., Hoernes, S. \& Schwark, L. 2003. Global changes during Carboniferous-Permian glaciation of Gondwana: Linking polar and equatorial climate evolution by geochemical proxies. Geology 31, 605-608.

DOI 10.1130/0091-7613(2003)031<0605:GCDCGO>2.0.CO;2

Schneider, J.W., Koerner, F., Roscher, M. \& Kroner, U. 2006. Permian climate development in the northern peri-Tethys area - The Lodeve basin, French Massif Central, compared in a European and global context. Palaeogeography, Palaeo- climatology, Palaeoecology 240, 161-183.

DOI 10.1016/j.palaeo.2006.03.057

SкоС̆EK, V. 1968. Svrchnokarbonské varvity ve středočeských kamenouhelných pánvích. Věstník Ústředního ústavu geologického 43, 113-121. [in Czech with English abstract]

Sкос̌Ек, V. 1990. Stephanian lacustrine-deltaic sequence in central and northeast Bohemia. Sborník geologických věd, Geologie 45, 91-122. [in Czech with English abstract]

Soreghan, M.J. \& Soreghan, G.S.L. 2007. Whole-rock geochemistry of upper Paleozoic loessite, western Pangaea: Implications for paleo-atmospheric circulation. Earth and Planetary Science Letters 255, 117-132. DOI 10.1016/j.eps1.2006.12.010

Stager, J.C., Ruzmaikin, A., Conway, D., Verburg, P. \& MaSON, P.J. 2007. Sunspots, El Nino, and the levels of Lake Victoria, East Africa. Journal of Geophysical Research, Atmospheres 112, D15106.

TABOR, N.J. \& Poulsen, C.J. 2008. Palaeoclimate across the Late Pennsylvanian-Early Permian tropical palaeolatitudes: A review of climate indicators, their distribution, and relation to palaeophysiographic climate factors. Palaeogeography, Palaeoclimatology, Palaeoecology 268, 293-310.

DOI 10.1016/j.palaeo.2008.03.052

TAlвот, M.R. \& Kelts, K. 1990. Palaeolimnological signatures from carbon and oxygen isotopic ratios in carbonates from organic-rich lacustrine sedimentas, 99-112. In KATZ, B.J. (ed.) Lacustrine Exploration: Case studies and Modern Analogues. AAPG Memoir 50.

Taylor, G.H., Teichmüller, M.T., Davis, A., Diesel, C.F.K., Littke, R. \& Robert, P. 1998. Organic Petrology. Gebrüder Borntraeger, Berlin \& Stuttgart.

TeichmüLler, M. 1974. Über neue macerale der Liptinit-Gruppe und die Entstehung von Micrinit, 37-64. In Bartenstein, H., Clausen, C.D., Heling, D., Hoyer, P., Leuteritz, K., Ottenjan, K., Teichmüller, M., Teichmüller, R., Thome, K.N. \& Wolf, M. (eds) Inkohlung und Erdöl.Beiträge der Kohlenpetrologie zur Prospection auf Erdöl und Erdgas. Fortschritte in der Geologie von Rheinland und Westfalen 24.

Teichmüller, M. \& Ottenjan, K. 1977. Art und Diagenese von Liptiniten und lipoiden Stoffen in einem Erdölmuttergestein auf Grund fluorescenzmikroskopischer Untersuchungen. Erdöl und Kohle 30, 387-398.

THOMSON, D.J. 1982. Spectrum estimation and harmonic analysis. Proceedings of the IEEE 70, 1055-1096.

DOI 10.1109/PROC.1982.12433

Usoskin, I.G. 2008. A History of Solar Activity over Milenia. Living reviews in Solar Physics 5, 7-60.

Veevers, J.J. \& Powell, C.M. 1987. Late Paleozoic glacial episodes in Gondwanaland reflected in trangressive-regressive depositional sequences in Euramerica. Geological Society of America Bulletin 98, 475-487. DOI 10.1130/0016-7606(1987)98<475:LPGEIG>2.0.CO;2

VISSER, J.N.J. 1997. Deglaciation sequences in the Permo-Carboniferous Karoo and Kalahari basins of southern Africa: A tool in the analysis of cyclic glaciomarine basin fills. Sedimentology 44, 507-521.

DOI 10.1046/j.1365-3091.1997.d01-35.x

WeEdon, G.P. 2003. Time-Series Analysis and Cyclostratigraphy. 259 pp. Cambridge University Press, Cambridge. DOI 10.1017/CBO9780511535482 


\section{Appendix 1}

Definitions and origin of dispersed organic macerals used in this study.

\begin{tabular}{|c|c|}
\hline Liptinite group & $\begin{array}{l}\text { Liptinite macerals are hydrogen-rich and considered to be produced from decayed leaf matter, spores, pollen and algal matter. } \\
\text { Resins and plant waxes can also be part of liptinite macerals. Liptinite macerals tend to retain their original plant form, i.e., } \\
\text { they resemble plant fossils. }\end{array}$ \\
\hline Alginite & $\begin{array}{l}\text { Alginite is formed from algal remains, it fluoresce brightly in shades of yellow under blue/ultraviolet light. It consists of } \\
\text { lamalginite composed thin-walled colonial or unicellular algae that occur as distinct laminae, cryptically interbedded with } \\
\text { mineral matter, and telalginite composed of large discretely occurring colonial or thick-walled unicellular algae such as } \\
\text { Botryococcus and Tasmanites. }\end{array}$ \\
\hline Bituminite & $\begin{array}{l}\text { Bituminite is a fine-grained ground mass in coals and in rocks and is considered to be derived from algae, bacterial bodies, } \\
\text { faunal plankton, animal bodies and other precursors. Degradation of primary biomass to bituminite is probably not purely } \\
\text { inorganic and partly carried out by bacteria. With increasing degree of diagenesis, alteration or weathering the reflectance of } \\
\text { bituminite rises and the fluorescence intesity decreases. }\end{array}$ \\
\hline Sporinite/Suberinite & $\begin{array}{l}\text { Sporinite is derived from the waxy coating of fossil spores and pollen. It forms flattened spheroids parallel to stratification. } \\
\text { Suberinite is defined only as suberinized cell walls in cork tissue, and cell cavities were usually filled by secondary gelification } \\
\text { materials. }\end{array}$ \\
\hline Resinite/Cutinite & $\begin{array}{l}\text { Resinite is originated from resins and waxes and occured as dicrete bodies of varying shape. Cutinite is derived from the } \\
\text { cuticles of leaves and stems. It occurs in sheet-like fragments and is very resistant to weathering. }\end{array}$ \\
\hline Liptodetrinite & $\begin{array}{l}\text { Liptodetrinite is particulated liptinite fragments (particle size }<10 \mu \mathrm{m} \text { ), it is produced by the mechanical disintegration and } \\
\text { chemical-microbiological degradation of algae, pollens, spores, cuticles, resins, waxes and pigments. }\end{array}$ \\
\hline Inertinite group & $\begin{array}{l}\text { The inertinite macerals are of diverse origin: i) tissues (of fungi or higher plants) showing structural details in various stages of } \\
\text { compaction or fracture, ii) fine detrital fragments, iii) gelified amorphous material of which the granular variety is generated } \\
\text { during coalification, and iv) cell secretions altered by redox and giochemical processes during peatification. }\end{array}$ \\
\hline Fusinite & $\begin{array}{l}\text { Fusinite comes mainly from woody material; it has high reflectivity and microhardness, well-preserved cellular structure, and } \\
\text { is high in carbon. It is mostly product of incomplete combustion derived from wild fires which resulted in the formation of } \\
\text { fossil charcoal, it can also generate by decarboxylation of plant tissues with the aid of fungi and bacteria, or by dehydration and } \\
\text { weathering. }\end{array}$ \\
\hline Semifusinite & $\begin{array}{l}\text { Semifusinite shows intermediate reflectance and structure between humotelinite/vitrinite and fusinite. It originates from woody } \\
\text { materials and tissues of stems, herbaceous plants and leaves, which are composed of cellulose and lignin. It is formed in the } \\
\text { peat stage by weak humification, dehydration and redox processes; oxidation during wildfires can also produce semifusinite. }\end{array}$ \\
\hline Macrinite & $\begin{array}{l}\text { Macrinite occurs either as an amorphous matrix or as discrete structureless ovoid bodies of variabel shapes. Macrinite } \\
\text { originates probably from flocculated humic matrix substances, it may also be a metabolic product of fungi and bacteria, and } \\
\text { isolated aggregates may originate from coprolites. }\end{array}$ \\
\hline Inertodetrinite & $\begin{array}{l}\text { Inertodetrinite consists of particulate inertinitic fragments (particle size }<10 \mu \mathrm{m} \text { ) without microscopically recognizable } \\
\text { structure. It has a variety of phytogenetic precursors, all of which have been subject to some degree of fusinitization. Many } \\
\text { particles of inertodetrinite are relics from wild-fires in or around the peatland. }\end{array}$ \\
\hline Funginite & $\begin{array}{l}\text { Funginite with partly visible original celular structure consists of mainly high reflecting single or multi-celled fungal spores, } \\
\text { sclerotia, hyphae and mycelia (stromata, mycorrhiza), and other fungal remains. }\end{array}$ \\
\hline Vitrinite group & $\begin{array}{l}\text { Vitrinite is considered to be composed of cellular plant material such as roots, bark, plant stems and tree trunks. Depending on } \\
\text { the process of decomposition, the degree of gelification and rank, cell structures are preserved and visible to varying extents. } \\
\text { The macerals of the vitrinite group are defined by the different structures resulting from different sources and pathways of } \\
\text { transformation within the mires. }\end{array}$ \\
\hline Telinite & $\begin{array}{l}\text { Maceral telinite consists of clearly recognizable cell walls of more-or-less intact plant tissue. The cell walls are always gelified, } \\
\text { and because of this they rarely show internal structure. }\end{array}$ \\
\hline Collotelinite & $\begin{array}{l}\text { Collotelinite consits of more-or-less homogenized vitrinite particles, which may exhibit poorly defined structure. The primary } \\
\text { structures disappear by geochemical gelification (vitrinitization). }\end{array}$ \\
\hline Detrovitrinite & $\begin{array}{l}\text { Detrovitrinite consists of finely fragmented vitrinitized plant remains (particle size }<10 \mu \mathrm{m} \text { ) occuring either isolated or } \\
\text { cemented by amorphous vitrinitic matter. The former structures have been broken down by chemical decay and/or mechanical } \\
\text { attrition. }\end{array}$ \\
\hline Gelovitrinite & $\begin{array}{l}\text { Gelovitrinite consists of colloidal infillings of vitrinitic material in former voids. It originated from the jelling of humic } \\
\text { solutions and not corresponding to specific plant tissues. It consists of colloidal infillings of vitrinitic material in former voids. } \\
\text { Gelovitrinite probably has more than one origin, but in general it is assumed that they are derived from the contents of plant } \\
\text { cells or from humic fluids formed from plant tissues during decay and diagenesis. }\end{array}$ \\
\hline
\end{tabular}

